NBER WORKING PAPER SERIES

\title{
FINANCIAL CONSTRAINTS AND GROWTH: MULTINATIONAL AND LOCAL FIRM RESPONSES TO CURRENCY CRISES
}

\author{
Mihir A. Desai \\ C. Fritz Foley \\ Kristin J. Forbes \\ Working Paper 10545 \\ http://www.nber.org/papers/w10545
NATIONAL BUREAU OF ECONOMIC RESEARCH
1050 Massachusetts Avenue
Cambridge, MA 02138
June 2004

The statistical analysis of firm-level data on U.S. multinational companies was conducted at the International Investment Division, Bureau of Economic Analysis, U.S. Department of Commerce under arrangements that maintain legal confidentiality requirements. The views expressed are those of the authors and do not reflect official positions of the U.S. Department of Commerce. The authors thank Malcolm Baker, Anusha Chari, Serdar Dinc, Mariassunta Giannetti, Jim Hines, Michael Schill, Andrei Shleifer, Kathy Terrell, Linda Tesar, Rohan Williamson, Bill Zeile and various seminar and conference participants for helpful comments. Desai thanks the Division of Research at Harvard Business School for financial support. The views expressed herein are those of the author(s) and not necessarily those of the National Bureau of Economic Research.

C2004 by Mihir A. Desai, C. Fritz Foley, and Kristin J. Forbes. All rights reserved. Short sections of text, not to exceed two paragraphs, may be quoted without explicit permission provided that full credit, including (C) notice, is given to the source. 
Financial Constraints and Growth: Multinational and Local Firm Responses to Currency Crises Mihir A. Desai, C. Fritz Foley, and Kristin J. Forbes

NBER Working Paper No. 10545

June 2004

JEL No. F23, F31, G15, G31, G32

\section{$\underline{\text { ABSTRACT }}$}

This paper studies the effects of financial constraints on firm growth by investigating if large depreciations differentially impact multinational affiliates and local firms in emerging markets. U.S. multinational affiliates increase sales, assets and investment significantly more than local firms during, and subsequent to, currency crises. The enhanced relative performance of multinationals is traced to their ability to use internal capital markets to capitalize on the competitiveness benefits of large depreciations. Investment specifications indicate that increases in leverage resulting from sharp depreciations constrain local firms from capitalizing on these investment opportunities, but do not constrain multinational affiliates. Multinational parents also infuse new capital in their affiliates after currency crises. These results indicate another role for foreign direct investment in emerging markets - multinational affiliates expand economic activity during currency crises when local firms are most constrained.

\author{
Mihir A. Desai \\ Harvard Business School \\ Morgan 363 \\ Soldiers Field \\ Boston, MA 02163 \\ and NBER \\ mdesai@hbs.edu
}

C. Fritz Foley University of Michigan Business School 701 Tappan Street Ann Arbor, MI 48109-1234 ffoley@bus.umich.edu
Kristin J. Forbes MIT-Sloan School

Room E52-455

50 Memorial Drive

Cambridge, MA 02142

and NBER

kjforbes@mit.edu 


\section{Introduction}

What happens to firm growth when a shock simultaneously improves investment opportunities and increases leverage and financial constraints? Are firms that have access to internal capital markets able to circumvent financial constraints and pursue growth opportunities? This paper investigates these questions by analyzing the response of U.S. multinational affiliates and local firms to large depreciations. Sharp exchange rate depreciations can improve the competitiveness of firms in the tradable sector, but in emerging markets these shocks often do not boost output or investment. This fact raises the possibility that increased leverage after depreciations (caused by the use of foreign currency denominated debt and the financial market conditions that frequently accompany currency crises) prevents firms from taking advantage of profitable growth opportunities. Unlike local firms, multinational affiliates have the ability (and have been shown) to use internal capital markets opportunistically when faced with financial constraints. Consequently, investigating the nature and sources of differential firm responses to these depreciations can illuminate the link between financial constraints and investment in unique ways.

The existing literature on financial constraints and growth struggles with several identification issues that are mitigated by comparing the responses of two types of firms to the same shock. For example, many cross-country studies use country level variables to proxy for financial development and are therefore subject to concerns of omitted variable bias. Similarly, many analyses of the effects of leverage on investment policies struggle with endogeneity; a negative relationship between leverage and growth may merely reflect the fact that managers facing poor growth opportunities choose high levels of leverage. Increases in leverage also may reflect a response to unobserved variation in investment opportunities. One way of addressing these concerns is to isolate a situation within a country in which an economic event that is exogenous to any individual firm simultaneously (i) improves investment opportunities, (ii) increases firm leverage or financing constraints, and (iii) increases financing constraints differentially across types of firms. 
Analyzing multinational and local firm responses to currency crises in emerging markets provides such a setting to investigate the relationship between financial constraints and investment decisions and the role of internal capital markets. Large depreciations are shown to improve the competitiveness of both local and multinational firms. At the same time, depreciations increase the leverage of firms that have borrowed in foreign currency and are unable to obtain new equity or adjust their capital structure. Such increases in leverage are observed for local firms, but not multinational affiliates, since affiliates are able to draw new capital from their parents and circumvent financial constraints. In addition to providing a test of how leverage influences investment, this differential reaction illustrates an effect of FDI not previously emphasized. FDI can mitigate output contractions during currency crises, since multinational affiliates expand activity precisely when local firms are most constrained. ${ }^{1}$

In order to perform the empirical analysis, we pool data on local firms and multinational affiliates. This new data set permits us to control for a variety of industry effects and to identify the relative performance of the two types of firms. We first investigate if multinational firms respond differently than local firms to currency crises by examining changes in sales, assets, and investment. The results indicate that, after depreciations, multinational affiliates increase sales and assets 5.4\% and 7.5\% more, respectively, than local firms. The improved relative performance of multinational affiliates is even more striking in investment. Capital expenditures are 34.5\% higher for multinational firms than local firms in the aftermath of large depreciations. These differences in performance between local firms and multinational affiliates do not appear to reflect different changes in investment opportunities stemming from differential access to global product markets or a disproportional reliance on local markets.

To identify the source of these differential investment responses across the two types of firms, we also investigate relative changes in operating profitability and leverage, proxies for how depreciations cause both competitiveness benefits and

\footnotetext{
${ }^{1}$ Analyses of the consequences of foreign direct investment (FDI) for host economies typically center on the presence of technology spillovers, the labor and environmental practices of multinational firms, or the effects of tax competition on the fiscal base of areas hoping to attract foreign direct investment. See, for example, Aitken and Harrison (1999), Harrison and McMillan (2003), Eskeland and Harrison (2003), and Figlio and Blonigen (2000).
} 
increased financing constraints. Although operating profitability responds similarly for the two types of firms before and after currency crises, local firms experience significantly larger increases in leverage than multinational firms after currency crises. We refine this analysis by using depreciation episodes as instruments for leverage and operating profitability in investment specifications. Results indicate that the investment response to the beneficial competitiveness effects of depreciations is not significantly different for the two types of firms. The investment response by local firms, however, is significantly constrained by increases in leverage caused by depreciations. In contrast, the investment response by multinational firms is not constrained by changes in leverage. These results suggest that the internal capital markets of multinational firms provide them with financing to increase investment after depreciations.

To further isolate how multinational affiliates circumvent local financing constraints, we examine more detailed multinational data that allow us to identify how financing patterns change in response to depreciations. The evidence indicates that multinational parents provide additional financing through intrafirm borrowing and equity infusions in response to sharp depreciations. These results provide further evidence that multinational firms overcome the negative consequences of large depreciations by ameliorating the financial constraints that handicap local firms.

Although the data set created for this analysis permits a novel approach for examining the relationship between financial constraints and investment decisions, it also has several shortcomings. In particular, the possibility of unobserved differences between local and multinational firms raises two primary concerns. First, we do not observe the currency denomination of debt. As a result, we are unable to document if local and multinational firms differentially use foreign currency denominated debt, and therefore we are unable to determine the extent to which increases in leverage are due to revaluations or other factors associated with currency crises. ${ }^{2}$ To overcome this

\footnotetext{
${ }^{2}$ The existing literature does not provide any direct guidance on whether multinational or local firms might be more likely to have dollar-denominated debt. Allayannis, Brown and Klapper (2003) study how firms choose between foreign and local debt but do not distinguish between local firms and multinational affiliates. This paper also points out how illiquidity in derivative markets might affect the capital structure and performance of firms during currency crises. Caballero and Krishnamurthy (2003) and Bris and Koskinen (2002) also indicate theoretically how different investment opportunities might motivate different currency denominations for financings.
} 
difficulty, our empirical approach uses measures of the total change in leverage in local currency terms around the time of depreciations to reflect changes in leverage arising from revaluations. Since we are interested in the effect of changes in leverage on investment, our identification strategy should be robust to this concern regardless of how borrowing decisions are denominated.

Second, it is possible that multinational and local firms differ with respect to their investment opportunities, particularly around currency crises. The relatively large panel in this data set, however, allows us to include a variety of fixed effects to control for investment opportunities specific to industry/years and country/industry/years. We are unable to use typical market-based measures of investment opportunities for affiliates since these firms are not publicly traded. Even if they were available, such market-based measures are particularly unreliable in emerging markets, especially during volatile periods around the time of currency crises. The primary concern related to not being able to control for market-based measures of investment opportunities is that the ability to export or the exposure to local markets may differ across local and affiliate firms. Robustness tests that restrict the analysis to local firms and affiliates that exclusively serve the local market, however, suggest that this is not a concern and confirm that growth and investment patterns differ for these two sets of firms for reasons associated with financial constraints.

The remainder of the paper is organized as follows. Section 2 motivates the subsequent analysis and empirical specifications in the context of a review of the existing literature. Section 3 identifies the depreciation episodes and describes the data set for local firms and multinational affiliates. Section 4 presents results on the relative performance of local and multinational firms around the depreciation episodes and examines sources of the distinct performance. Section 5 provides a more detailed analysis of how multinational firms change financing patterns in response to currency crises. Section 6 concludes.

\section{2. $\quad$ Related Literature and Empirical Methodology}

Our analysis of the relative performance of multinational and local firms during currency crises integrates the literature on firm performance during currency crises with 
the literature on how access to global markets affects firm performance. The literature on firm performance during currency crises is closely tied to the larger finance literature on debt overhang and the link between financial constraints and investment. In this section, we review these literatures and then outline our empirical methodology.

\subsection{Firm Performance During Currency Crises}

Sharp depreciations can benefit local firms by raising the price of imports (causing consumers to substitute toward domestically-produced goods) and by lowering production costs relative to foreign competitors (providing a cost advantage in export markets). ${ }^{3}$ Krueger and Tornell (1999) provide empirical evidence of this competitiveness effect at the sectoral level, and Aguiar (2002) and Forbes (2002a, 2002b) provide empirical evidence at the firm-level. ${ }^{4}$ In particular, Forbes (2002b) shows that firms with greater foreign sales exposure are more likely to have higher growth in sales, net income, market capitalization, and assets after depreciations. Evidence on the aggregate effect of sharp devaluations on output, however, is mixed. For example, both Agénor and Montiel (1996) and Gupta, Mishra and Sahay (2000) find that currency crises can have contractionary or expansionary effects, on aggregate, in different countries. Calvo and Reinhart (2000) distinguish between emerging and developed markets and conclude that currency crises in emerging markets are more likely to have large contractionary effects.

These mixed results, and especially the differential effect of devaluations in emerging and developed markets, have motivated several papers investigating factors that might offset the positive competitiveness effects described above. Most of this work considers how sharp depreciations can increase financial constraints. ${ }^{5}$ In a costly state verification model, Bernanke and Gertler (1989) show how deteriorating balance sheets can play an important role in explaining patterns of macroeconomic activity. When a large share of liabilities is denominated in a foreign currency, as is common in emerging

\footnotetext{
${ }^{3}$ An important determinant of the magnitude of these effects is the extent to which exchange rate movements are "passed through" into local prices. Numerous studies, many of which are summarized in Goldberg and Knetter (1997), find that exchange rate pass through is incomplete.

${ }^{4}$ Johnson et al. (2000) and Mitton (2002) emphasize the importance of corporate governance in determining how devaluations affect firm stock prices during the Asian crises.

${ }^{5}$ Several papers, such as Edwards (1989) and Reif (2001), instead focus on how depreciations can raise the cost of imported inputs, thereby diminishing any positive competitiveness effect on firm performance.
} 
markets, depreciations can aggravate credit constraints and worsen balance sheets, thereby hindering investment. ${ }^{6}$

As noted by Stein (2003), these macroeconomic models are closely related to the larger literature that links financial constraints, stemming from various factors, to investment. This literature typically isolates a shock to one part of a firm and examines how leverage, stock prices or cash flow (as in Lang, Ofek and Stulz (1995), Peek and Rosengren (1997) and Lamont (1997), respectively) determine a firm’s subsequent investment behavior. In contrast to these studies, a comparison of the responses of local and multinational firms has several advantages. First, the shock simultaneously improves investment opportunities and increases leverage providing more robust identification of the link between financial constraints and investment. Second, the fact that multinational firms access internal capital markets (and we can observe these transactions) allows us to confirm the mechanisms by which firms circumvent financing constraints. Indeed, Lamont (1997) concludes with the suggestion that sharp depreciations might usefully be employed to investigate how financing constraints restrict investment. ${ }^{7}$

Existing work that investigates currency crises and the interaction of competitiveness effects and credit constraints has not reached definitive conclusions. Both Aguiar (2002) and Bleakley and Cowan (2002) attempt to determine which effect dominates, but the two papers reach opposing conclusions. ${ }^{8}$ The analysis performed in this paper of how multinationals and local firms respond differently to currency crises can provide further insight on this question by comparing how firms with differential

\footnotetext{
${ }^{6}$ See Aghion, Bachetta and Banerjee (2001) and Caballero and Krishnamurthy (2001) for formal models of how depreciations can interact with credit constraints to cause large output contractions. For a review of the extensive evidence on capital market imperfections and investment, see Hubbard (1998).

${ }^{7}$ This link between investment and leverage is modeled as a debt overhang problem in Myers (1977), and examined empirically in Whited (1992), Lang, Ofek and Stulz (1995) and Hennessy (2003). A related literature attempts to describe the effect of financing constraints by analyzing investment-cash flow sensitivities as detailed in Fazzari, Hubbard and Petersen (1988, 2000) and Kaplan and Zingales (1997, 2000). Currency crises provides a setting where investment opportunities improve and, as argued below, financing constraints are differentially increased across types of firms, thereby circumventing some of the difficult identification issues described in those papers.

${ }^{8}$ Aguiar (2002) shows that balance-sheet effects significantly constrained investment in Mexican firms after the 1994 peso crisis. On the other hand, Bleakley and Cowan (2002) find that any balance-sheet effects are outweighed by the positive competitiveness effects of depreciations for firms from 5 Latin American countries between 1990 and 1999. In related work, Allayanis, Brown and Klapper (2003) find no relationship between stock market performance and the use of foreign currency debt.
} 
access to capital respond to the improved investment opportunities that accompany sharp depreciations. $^{9}$

\subsection{Firm Performance and Access to International Markets}

A large body of work indicates that access to international sources of capital can allow firms to overcome constraints associated with local capital markets, especially in emerging markets. Some of this evidence comes from changes in financial openness. Stulz (1999) shows that financial market liberalizations can reduce the cost of capital for local firms. Henry (2000a) and Bekaert and Harvey (2000) show that liberalizations increase stock market valuations, and Henry (2000b) shows that they also are associated with investment booms.

Access to global capital markets may also affect the relative performance of the subset of firms in an economy that can access those markets. Desai, Foley and Hines (2003) analyze how multinationals capitalize affiliates around the world and demonstrate that multinational affiliates substitute internal borrowing for costly external finance stemming from adverse capital market conditions. In a related vein, Desai, Foley and Hines (2004) demonstrate that affiliates of multinationals firms employ internal product and capital markets to circumvent capital controls in a manner that is unlikely to be available to local firms.

Differential access to global markets may also help explain aggregate patterns of FDI. Froot and Stein (1991) explain the correlation between FDI inflows and currency devaluations with a model in which capital market imperfections limit the ability of local firms to access external markets, thus giving foreign firms an advantage in bidding for assets. Aguiar and Gopinath (2003) study the frequency and terms of cross-border mergers and acquisitions subsequent to currency crises in Asia. They present evidence that foreign firms buy assets at times that local firms may be liquidity constrained. Blonigen (1997) provides evidence that firm-specific assets (such as intangibles) become more highly valued by foreign acquirers during depreciations, since product market

\footnotetext{
${ }^{9}$ By comparing the investment responses of firms differentially impacted by leverage within a given industry, this empirical strategy mirrors that of examining entry by supermarket chains in regions dominated by LBO-supermarkets in Chevalier (1995). As with the results in that paper, our results indicate that differential changes in leverage lead to changes in the competitive environment of firms.
} 
imperfections allow these acquirers to better mobilize those assets abroad in the more highly valued currency. This series of papers suggests that access to global markets may be an important determinant of firm performance, and could benefit multinational firms more than local firms during currency crises.

\subsection{Empirical Methodology}

If multinationals are able to access internal capital markets in order to capitalize on competitiveness effects, then these firms should be able to increase their output and the scale of their activity more than local firms in the wake of depreciations. Therefore, we begin our empirical analysis by evaluating firm sales, assets, and investment using the following specification:

$$
\begin{aligned}
& Y_{i, j, k, t}=\theta_{1} \text { Depreciation }(t-1)_{k, t}+\theta_{2} \text { Depreciation }(t)_{k, t}+\theta_{3} \text { Depreciation }(t+1)_{k, t}+\theta_{4} \text { Depreciation }(t+2)_{k, t} \\
& \text { (1) }+\theta_{5} \text { Multinational }_{i}^{*} \text { Depreciation }(t-1)_{k, t}+\theta_{6} \text { Multinational }_{i} * \text { Depreciation }(t)_{k, t} \\
& \left.\left.+\theta_{7} \text { Multinational }_{i} * \text { Depreciation }_{(} t+1\right)_{k, t}+\theta_{8} \text { Multinational }_{i} * \text { Depreciation }_{(}+2\right)_{k, t} \\
& +\theta_{9} X_{i, j, k, t}+\eta_{j, t}+\alpha_{i}+\varepsilon_{i, t}
\end{aligned}
$$

where $i$ is a subscript for each firm, $j$ is a subscript for each industry, $k$ is a subscript for each country, $t$ is a subscript for each year; $Y_{i, j, k, t}$ is a measure of operating activity (such as sales growth or capital expenditures); the depreciation dummy variables are respectively set equal to 1 for observations from one year before (t-1), the year of $(\mathrm{t})$, one year after $(\mathrm{t}+1)$, and two years after $(\mathrm{t}+2)$ a depreciation in country $k$; Multinational $_{i}$ is a dummy variable equal to 1 if company $i$ is a multinational affiliate; $X_{i, j, k, t}$ is a set of firmspecific, time-varying controls including variables that account for producer-price inflation; $\eta_{\mathrm{j}, \mathrm{t}}$ is a set of industry-year dummy fixed effects; $\alpha_{i}$ is a firm-specific effect; and $\varepsilon_{i, t}$ is an error term. Industries are defined at the three-digit SIC level. All standard errors are clustered at the firm level to correct for serial correlation. ${ }^{10}$

The key variables of interest are the coefficients on the depreciation dummy variables and on these dummies interacted with the dummy variable for multinational

\footnotetext{
${ }^{10}$ See Bertrand, Duflo, and Mullainathan (2004). Results are qualitatively similar if standard errors are clustered by country. As a robustness test, we also estimate specifications which include country/industry/year fixed effects, using industry groupings similar to two-digit SIC codes. In these specifications, it is only possible to identify a set of depreciation dummies that capture the difference between the response of multinationals and local firms to depreciations, and the sample only includes firms in countries that experience depreciations. These specifications confirm the results presented in the paper.
} 
affiliates. The depreciation dummies measure the response of local firms to depreciations, and the interaction terms capture the incremental performance of multinational affiliates relative to local firms. To facilitate calculations of the persistent effects of depreciations, we also estimate some specifications with only two depreciation dummies; the first is equal to one for observations in the year before a depreciation, and the second is equal to one for observations in the year of and each of the two years following a depreciation. Following Evans (1987a) and other empirical work on the growth of firms, we include the initial value of the relevant measure of operating activity when the dependent variable is measured as a growth rate. ${ }^{11}$ All specifications include a fixed effect for each industry/year pair in order to control for time varying patterns in industry performance and investment opportunities.

Evidence of distinct responses for multinational and local firms does not, by itself, indicate the extent to which competitiveness benefits or changes in financial constraints explain differences in performance. As a first step in untangling these effects, we use measures of operating profits and leverage as dependent variables in specifications that are similar to equation (1). These specifications allow us to test if either competitiveness effects or financial constraints change for local and multinational firms around currency crises.

Next, we link changes in operating profits and leverage to changes in investment through a specification that builds closely on the debt overhang specification in Lang, Ofek, and Stulz (1995). Since investment, leverage, and operating profits may be jointly determined, we employ depreciation episode dummies and these dummies interacted with the multinational dummy as instruments for changes in leverage and operating profits in order to obtain unbiased estimates. Firm investment in a particular year is the dependent variable in this specification, and predicted values of operating profits and leverage are independent variables. Predicted values are based on specifications using equation (1). These instruments should be valid if depreciations impact investment exclusively through changes in competitiveness and financing constraints, as suggested in the literature. ${ }^{12}$ In

\footnotetext{
${ }^{11}$ For other work on the growth of firms, see Evans (1987b) and Hall (1987).

${ }^{12}$ One potential shortcoming of this setup is that operating profits may not adequately capture investment opportunities. If local firms increase leverage because they face poor investment opportunities, then the
} 
these specifications, the coefficient on operating profits indicates the importance of changed investment opportunities arising from competitiveness effects, and the coefficient on leverage indicates the changed importance of financing constraints. As in the specification outlined in equation (1), we also include interactions with a dummy variable for multinational firms to isolate any distinct financing constraints and competitiveness effects for multinational firms.

Finally, we employ more detailed data on multinational affiliates to examine if changed financing patterns might explain the distinct reactions to currency crises. The empirical setup is similar to the one outlined in equation (1), with the exception that the dependent variables are measures of intrafirm financing - such as related party lending and paid-in capital. There are also no multinational dummy variables since similar data are not available for local firms.

\section{The Firm-level Dataset and Depreciation Episodes}

\subsection{The Firm-Level Dataset}

The firm-level data set used in this paper is compiled from two major sources: the Bureau of Economic Analysis (BEA), which provides information on affiliates of U.S. multinationals, and Worldscope, which provides information on local firms. The Bureau of Economic Analysis (BEA) annual survey of U.S. Direct Investment Abroad from 1991 through 1999 provides a panel of data on the financial and operating characteristics of U.S. firms operating abroad. These surveys ask reporters to file detailed financial and operating items for each affiliate, as well as information on the value of transactions between U.S. parents and their foreign affiliates. The International Investment and Trade in Services Survey Act governs the collection of the data. The Act ensures that "use of an individual company's data for tax, investigative, or regulatory purposes is prohibited.” Willful noncompliance with the Act can result in penalties of up to $\$ 10,000$ or a prison term of one year. As a result of these assurances and penalties, BEA believes that coverage is close to complete and levels of accuracy are high.

coefficient on leverage may simply reflect the choice of leverage in response to competitiveness effects and not the consequences of changed financial constraints. This is unlikely to be the case since depreciations should boost the competitiveness of the tradable sector, thus creating limited incentive to increase leverage. 


\section{U.S. direct investment abroad is defined as the direct or indirect ownership or} control by a single U.S. legal entity of at least ten percent of the voting securities of an incorporated foreign business enterprise, or the equivalent interest in an unincorporated foreign business enterprise. A U.S. multinational entity is the combination of a single U.S. legal entity that has made the direct investment, called the U.S. parent, and at least one foreign business enterprise, called the foreign affiliate. ${ }^{13}$ The foreign affiliate survey forms that U.S. multinational firms are required to complete vary depending on the year, the size of the affiliate, and the U.S. parent's percentage of ownership of the affiliate. The most extensive data are available for 1994 and 1999, when BEA conducted Benchmark Surveys. ${ }^{14}$ BEA collects identifiers linking affiliates through time, thereby permitting the creation of a panel.

The second major source of firm-level data is the Worldscope database produced by Thompson Financial. This database provides information on local firms and contains annual balance sheet, income statement, cash flow, and general company information for companies based around the world. Firms are identified as local based on the country in which they are incorporated. Since the database is derived from publicly-available information, virtually all of the sample consists of publicly-traded companies, so that smaller and government-owned companies are underrepresented. ${ }^{15}$ Worldscope coverage of public companies, however, is fairly extensive. For example, the September 2002 CDROM includes information for over 20,000 firms from 55 countries, representing over

\footnotetext{
${ }^{13}$ In order to be considered as a legitimate foreign affiliate, the foreign business enterprise should be paying foreign income taxes, have a substantial physical presence abroad, have separate financial records, and should take title to the goods it sells and receive revenue from the sale. In order to determine ownership stakes in the presence of indirect ownership, BEA determines the percentage of parent ownership at each link and then multiplies these percentages to compute the parent's total effective ownership.

${ }^{14}$ In non-benchmark years, reporting exemption levels were higher and less information is collected. Although wholly-owned and majority-owned affiliates report many accounting items and information concerning operations each year, minority-owned affiliates need only file information about sales, net income, assets, employment, employment compensation, and trade with the United States in nonbenchmark years. Majority-owned affiliates are foreign affiliates in which the combined direct and indirect ownership claim by a U.S. parent exceeds 50 percent.

${ }^{15}$ There are several limitations with this data. First, although Worldscope attempts to correct for major differences in cross-country accounting standards, significant differences may still exist for certain variables. The analysis below addresses this problem by controlling for firm fixed effects. Second, there are a number of extreme and unrealistic outliers that undoubtedly represent reporting errors. The analysis below addresses this problem by performing an extensive set of sensitivity tests that includes removing outliers. Third, there is some chance that local firms are actually affiliates of multinationals based elsewhere in the world. Since U.S. parents wholly own more than $80 \%$ of their affiliates and affiliates are rarely publicly traded, however, there is little chance that firms classified as local are in fact U.S. MNEs.
} 
$96 \%$ of global market capitalization. While most of the Worldscope data used in this paper are drawn from the September 2002 CD-ROM, we augment these data with information from the September 1997 CD-ROM, since Worldscope reports no more than 10 years of historical company information on each CD-ROM. ${ }^{16}$

We merge the Worldscope and BEA data. Then we create a common set of industry codes by translating the SIC codes in the Worldscope data into the ISI codes used by the BEA, which are roughly equivalent to three-digit SIC codes. In order to limit the sample to those firms that are likely to experience competitiveness effects from depreciations, we exclude all firms that produce non-tradable goods and services. ${ }^{17} \mathrm{We}$ also limit the sample to data from 1991 through 1999, which is the time period available for both data sources. Finally, we exclude firms missing information for key variables, such as sales.

\subsection{Depreciation Episodes}

In order to identify how depreciations affect multinational affiliates and local firms, it is necessary to identify a series of depreciation episodes in emerging markets. We compute real exchange rates by first obtaining daily U.S. dollar exchange rates reported by Datastream for all available emerging markets from January 1990 through January 2000. Then we adjust these nominal exchange rates for inflation differentials using interpolated price data drawn from the IMF (2003). ${ }^{18}$ We define depreciation episodes as periods when the real exchange rate increases by over $25 \%$ compared to the value of the exchange rate one year earlier. ${ }^{19}$ Therefore, depreciation episodes include not

\footnotetext{
${ }^{16}$ We match companies across datasets based on company numbers, sedol numbers, and/or company names. Then we test if the time series across the two datasets is consistent for seven data series: cash and equivalents, total assets, total liabilities, equity, sales, net income, and sales in U.S. dollars. If the time series for each of these variables is not consistent across the two CD-ROMs, the company is not treated as a "match" across the two data sources.

${ }^{17}$ More specifically, the resulting sample includes firms whose main BEA industry classification is in any industry between 010 and 0390 except for $070,108,124,138,148$, and 150 . The sample therefore includes firms that are active in the following broad categories of activity: agriculture, forestry, and fishing; mining; and manufacturing.

${ }^{18}$ Price adjustments are based on annual producer prices (line 63..zf) whenever possible. If producer prices are not available, we use consumer prices (line 64..zf), or the most relevant price data available. Quarterly or monthly price information is not available for a majority of countries in the sample.

${ }^{19}$ If a country experiences a depreciation episode in a given year, the next year is excluded, so that a country can experience, at most, one depreciation event in any 2-year period. Moderate adjustments to the cutoff to qualify as a depreciation episode do not significantly affect the key results.
} 
only “currency crises” when a country’s real exchange rate depreciates abruptly by at least $25 \%$ within a short window of time, but also periods when a country's exchange rate depreciates slowly for a cumulative depreciation of at least $25 \%$ within a year. ${ }^{20}$

This method of identifying depreciation episodes has two advantages over the strategies frequently used in past work. First, by focusing on depreciations over longer periods of time, it captures any large depreciations that occur in small increments (such as a 5 percent depreciation each month for several months) rather than just one-time large depreciations. Second, previous work using high frequency exchange rate data has not directly accounted for inflation. Studies often just exclude high-inflation countries, since large nominal depreciations combined with high inflation can be poor measures of real changes in competitiveness. By focusing on longer depreciation windows it is possible to adjust for differences in relative price movements and thereby calculate real, instead of nominal, depreciations. Moreover, since this analysis focuses on testing how depreciations affect firm activities, real depreciations are more relevant than nominal ones.

Next, in order to identify which countries are emerging markets, we use the classification from the back of the Economist. ${ }^{21}$ We then exclude all countries for which there is no information in either of the two sources of firm-level data. Finally, we also exclude any country-years in which a country experiences inflation of over 100 percent, because it is difficult to accurately measure firm operating activity during periods of hyperinflation.

\subsection{Summary Information}

The resulting sample includes firms in 25 emerging markets, 15 of which experience a depreciation episode. Table 1 provides information on country coverage and the share of firms drawn from the BEA and Worldscope samples. The first column

\footnotetext{
${ }^{20}$ Many other macroeconomic changes often accompany currency crises. For example, Beck, DemirgucKunt, and Levine (2003) and Caprio and Klingebiel (1999) demonstrate that banking crises often occur at the same time as currency crises in emerging markets. We emphasize large depreciations in order to identify events when firms in the tradable sector have incentives to expand, but local financial conditions may prevent firms from capitalizing on those new investment opportunities.

${ }^{21}$ The only exception is the Slovak Republic that is not included in the section on emerging markets or developed countries in the back of the Economist. We classify the Slovak Republic as an emerging market (which is the same classification as the Czech Republic).
} 
of the table shows that there is a strong clustering in depreciation episodes, with several depreciations around the time of the 1994 Mexican Peso Crisis, and another set of depreciations around the 1997-98 Asian/Russian crises.

The right-hand columns in Table 1 also show that there are roughly equal numbers of local and multinational firms across the sample period. In the group of countries that experience depreciations, $49 \%$ of the sample is classified as local firms. In the control group of countries (which do not experience depreciations), 45\% of the sample is classified as local firms. No more than $15 \%$ of the total observations are drawn from any single country. Although multinational affiliates dominate the samples in Mexico and Venezuela, local firms and multinational affiliates each comprise at least $20 \%$ of the sample in every other country.

Table 2 provides descriptive statistics for the variables used in the empirical analysis, separated for local firms and multinational affiliates. The bottom of Table 2 also reports descriptive statistics for the variables only available for multinational affiliates and used in Section 5. Appendix Table 1 provides information on the number of affiliates and local firms by industry.

\section{Firm Performance during Currency Crises}

In order to investigate the relative performance of multinational affiliates and local firms during currency crises, we begin with a simple, bivariate comparison of their differential reactions. Figure 1 suggests that the response of multinationals to depreciations, as measured by the growth in sales and assets, is quite distinctive from that of local firms. Panel A shows that the median sales growth of multinational affiliates is almost identical to that of local firms in the year prior to depreciations. In the year of, and each of the two years following depreciations, however, the median sales growth of multinational affiliates exceeds that of local firms by considerable margins. While median sales growth for multinational affiliates is higher after depreciations than before, median sales growth for local firms is lower after depreciations than before.

Panel B illustrates similar patterns for median asset growth rates. Although multinational affiliates have slightly lower asset growth than local firms in the year before depreciations, multinational affiliates have median asset growth more than twice 
as large as local firm asset growth in the year of and the two years after depreciations. The asset growth of multinational affiliates exceeds its pre-depreciation level in the year of and the two years after depreciations, but the asset growth of local firms increases by only a modest amount in the year of a depreciation, and then falls below its predepreciation levels.

A similar analysis of leverage and operating profitability presented in Figure 2 also shows substantial differences across the two types of firms. These patterns support a potential role for both financing constraints and competitiveness benefits in explaining why affiliates increase assets and sales more than local firms during depreciations. Leverage is measured as the ratio of current liabilities and long term debt to assets and Panel A shows that affiliates have slightly lower levels of leverage than local firms in the year before depreciations. Although local firms experience increases in leverage in the year of a depreciation that persist in the following two years, affiliates experience only a temporary increase in leverage in the year of a depreciation.

Panel B of Figure 2 shows patterns in operating profitability, which is defined as the ratio of sales less operating expenses to sales. ${ }^{22}$ It shows that in the year before depreciations, affiliates experience operating profitability that is approximately 1 percentage point greater than local firms. Operating profitability increases for both types of firms in the year of depreciations, suggesting that companies immediately benefit from competitiveness effects. In the year following depreciations, median operating profitability of both types of firms contracts, but remains above pre-depreciation levels. The descriptive data for the two years after depreciations indicate that the operating profitability of local firms and affiliates diverge. Since firms drop in and out of the sample in this bivariate analysis, it is critical to employ firm fixed effects in the following regression framework to see if these patterns persist in a more thorough analysis.

\subsection{Do Multinational Affiliates Perform Differently During Currency Crises?}

Table 3 analyzes the levels and growth of sales and assets around the time of depreciations using the specification in equation (1). The dependent variable in columns

\footnotetext{
${ }^{22}$ Operating expenses include selling, general, and administrative expenses but exclude interest expenses. Therefore, they do not reflect financing costs but do include some fixed costs.
} 
1 and 2 is the log of sales (measured in nominal local currency units), so that the coefficients on the depreciation dummies are interpreted as the value of sales relative to mean firm sales, after controlling for individual industry/year fixed effects. The coefficient estimates in column 1 indicate that sales of local firms increase slightly at the time of depreciations, and then fall below their pre-depreciation levels in the year after and two years after a depreciation. The coefficient estimates of -0.0787 and -0.1270 on the depreciation $\mathrm{n}_{\mathrm{t}+1}$ and depreciation $\mathrm{t}_{\mathrm{t}+2}$ dummies imply, relative to the -0.0712 coefficient on the depreciation ${ }_{\mathrm{t}-1}$ dummy, that sales are 0.7 and 5.6 percentage points lower in the year following and two years following a depreciation, as compared to the year before a depreciation. An F-test indicates that the difference between the level of local firm sales in the year before a depreciation and the level two years after a depreciation is only marginally significant at the $10 \%$ level. The coefficients on the multinational depreciation interactions, however, indicate that sales of multinational affiliates do not decline after depreciations. The large, positive and significant coefficients on the post depreciation dummies for multinationals imply that affiliate sales increase relative to the sales of local firms after depreciations.

Column 2 of Table 3 presents results for the same specification as in Column 1, except the dummies for the year of a depreciation and the two subsequent years are combined into a single dummy variable that is equal to one for all three of these years. The -0.0852 coefficient on the post depreciation dummy is slightly less than the dummy capturing the pre-depreciation level of sales, indicating a small but statistically insignificant decline in sales for local firms, on average, after depreciations. The level of sales of multinational affiliates is indistinguishable from that of local firms in the year before a depreciation. The 0.0841 coefficient on the interaction between the multinational and post depreciation dummy, however, implies that the sales of affiliates are 8.4 percentage points higher than the sales of local firms after depreciations.

Columns 3 and 4 of Table 3 analyze sales' growth rates (measured as the difference in log values) instead of the level of sales. ${ }^{23}$ This approach has the advantage

\footnotetext{
${ }^{23}$ Since lagged values are required to compute growth rates, all observations from 1991 and all other observations of local firms and multinational affiliates that did not report in the previous period are dropped from the analysis.
} 
of automatically excluding multinational affiliates that are extremely small and only appear in benchmark years, thereby ensuring that the results are not merely a byproduct of large changes in small affiliates. The coefficient estimates are deviations from average growth rates. The estimates suggest that multinational affiliates have faster sales growth than local firms after depreciations. More specifically, column 3 indicates that in the year of and year after depreciations, local firms experience significantly lower average sales growth than before depreciations. In contrast, multinational affiliates have higher sales growth than local firms after depreciations, and this difference is highly significant in the year following depreciations. These patterns are even clearer in Column 4 when the years following depreciations are considered jointly. Local firms have significantly lower sales growth after depreciations while the sales growth of multinational affiliates is 5.4 percentage points faster than that of local firms following depreciations.

The last four columns of Table 3 repeat this analysis but employ the log of assets instead of sales as the dependent variable. Using firm size, as measured by assets, allows us to investigate if the output effects identified above are also associated with greater firm scale. The results indicate that multinationals expand assets more than local firms subsequent to depreciations. Column 5 shows that local firms' asset levels increase in the year of a depreciation, and then contract in the two subsequent years, so that after a depreciation asset levels for local firms are statistically indistinguishable from their predepreciation levels. In contrast, multinational affiliates' asset levels increase significantly after depreciations and remain significantly above their pre-depreciation levels in the two years after depreciations. The results in column 6 confirm that the asset base of multinational affiliates expands by significantly more than the asset base of local firms after depreciations.

The last two columns in Table 3 employ asset growth as the dependent variable, instead of the log of assets. Column 7 suggests that average asset growth for local firms was slightly higher in the year of depreciations than before, but significantly below average (by 6.2 and 5.0 percentage points, respectively) in the two years following depreciations. In contrast, asset growth for multinational affiliates significantly exceeded that for local firms in the year of depreciations. The difference in growth rates is a statistically significant 15 percentage points. Column 8 confirms that the asset growth of 
multinational affiliates was significantly greater than that of local firms in the period during and after depreciations.

Table 4 analyzes the investment behavior of local and multinational firms during depreciations. It uses two measures of investment as dependent variables: the log of capital expenditures and capital expenditures scaled by net property plant and equipment. Column 1 shows that although capital expenditures are not significantly different from their mean levels for local firms in the year before or year of depreciations, investment falls significantly in the two years following depreciations. In contrast, capital expenditures increase significantly for multinational firms in the two years after depreciations. The results in column 2, using a single post-depreciation dummy, confirm these conclusions. Investment by local firms is 41 percentage points below predepreciations levels after depreciations. Investment by multinational affiliates after depreciations, however, is 34 percentage points higher than investment by local firms, and F-tests indicate that the level of affiliate capital expenditures in the year of and year following a depreciation differ from the level in the year before a depreciation by amounts that are statistically significant at the $5 \%$ level.

Different levels of investment between multinational affiliates and local firms may simply reflect differences in their scope of activity following depreciations, instead of differences in the investment responses of entities of a similar size. To rule out this possibility, Columns 3 and 4 of Table 4 use capital expenditures scaled by end-of-period net property, plant and equipment (PPE) as the dependent variable. The results confirm those reported in columns 1 and 2. After scaling by net PPE, local firm investment falls below pre-depreciation levels after depreciations, but multinational affiliate investment does not.

\subsection{The Determinants of Differential Investment Responses}

The evidence presented in Tables 3 and 4 demonstrates the differential reaction of multinational affiliates and local firms to currency crises. As discussed in Section 2, the competitiveness benefits of sharp depreciations would be expected to boost firm sales, assets and investment, but these effects could be outweighed by changed financing constraints. The results showing the distinctive response to currency crises between these 
two types of firms are consistent with two alternative hypotheses. First, it is possible that both types of firms benefit from competitiveness effects, but local firms experience large changes in financial constraints that counteract any competitiveness effects from depreciations. Alternatively, competitiveness effects may be stronger for multinational affiliates, and these effects alone may drive the differences in relative performance.

In order to disentangle these alternative explanations, we begin by examining the effect of depreciations on operating profits, which is a measure of competitiveness effects, and leverage, which is a measure of changed financing constraints. The specifications in columns 1 and 2 of Table 5 employ the log of operating profits as the dependent variable in specifications similar to those presented in Tables 3 and 4 . The results indicate that in the year of and two years after depreciations, operating profits of local firms exceed their pre-depreciation levels. ${ }^{24}$ The operating profits of multinational affiliates also increase after depreciations, but are not significantly different from the levels for local firms in the year before, the year of, and the year after depreciations. In short, sharp depreciations are associated with significant improvements in operating profits for both local firms and multinational affiliates, suggesting that competitiveness effects are important for both sets of firms. ${ }^{25}$ These results contrast with the distinctive performance of multinational and local firms documented in Tables 3 and 4 with respect to sales, assets, and investment.

To test for the presence of distinctive changes in financial constraints across the two sets of firms, columns 3 and 4 of Table 5 employ leverage as the dependent variable in specifications similar to the specifications in columns 1 and 2. Leverage is measured as the ratio of a firm's current liabilities and long term debt to assets. The leverage of local firms increases significantly in the year of depreciations, but the leverage of multinational affiliates does not. In fact, local firm leverage increases to levels higher than both average and pre-depreciation levels in the year of and each of the two years

\footnotetext{
${ }^{24}$ F-tests indicate that these differences are significant at the 1\% level for the year of depreciations, $10 \%$ level for the year after depreciations, and 5\% level for the second year after depreciations.

${ }^{25}$ Since the results in Table 3 indicate that the sizes of local firms and affiliates change around the time of depreciations, it is informative to examine local firm and affiliate operating profitability, or operating profits scaled by sales. These results are broadly consistent with those presented for operating profits. Similarly, gross profits, a measure of profits that does not incorporate overhead expenses but is only available for local firms, also provides evidence of increased profitability subsequent to depreciations.
} 
following depreciations. These increases are expected if firms borrow in foreign currency and are not able to improve their balance sheets after a currency crisis. The coefficients on the interaction terms with the multinational dummy variables, however, show that leverage does not increase for affiliates. While both types of firms appear to experience similar competitiveness benefits after depreciations (as measured by changes in operating profits), only local firms experience large changes in leverage. This suggests that financing constraints are limiting local firm responses, but not multinational affiliate responses, to depreciations.

To more rigorously test this interpretation, we extend the above analysis by linking the changed operating profits and leverage arising from depreciations to observed patterns of investment. As discussed above, investment, leverage, and operating profits may be jointly determined. Therefore, we employ depreciation episode dummies and these dummies interacted with the multinational dummies as instruments for changes in leverage and operating profits. The log of capital expenditures is the dependent variable in this specification, and predicted values of operating profits and leverage are independent variables. The first stage specifications used to obtain predicted values are the same as the specifications presented in Table 5. In the specifications provided in Table 6, the coefficient on operating profits indicates the importance of changed investment opportunities arising from competitiveness effects and the coefficient on leverage indicates the importance of changed financing constraints. ${ }^{26}$ The interactions with a dummy variable for multinational firms isolate the distinct effect of financing constraints and competitiveness benefits for multinational firms.

We first estimate specifications that only include controls for either leverage or operating profits plus the standard controls for the prices, industry/year fixed effects and firm fixed effects. Column 1 of Table 6 indicates that firms with higher leverage after

\footnotetext{
${ }^{26}$ Tobin's Q is often used in investment specifications to characterize investment opportunities. Not only is this measure problematic - especially in emerging markets where stock market valuations may not reflect underlying fundamentals — but clean measures of Tobin's Q are unavailable for multinational affiliates since these firms are not publicly traded. Therefore, we rely on operating profits and industry/year fixed effects to proxy for changed investment opportunities. As a robustness test, we have also included fixed effects for each country/industry/year to capture investment opportunities more precisely. Specifications with these fixed effects are estimated using only firms in crisis countries and leverage and competitiveness effects are identified off of differences in the responses of local firms and affiliates. The results also show that changes in leverage induced by depreciations constrain investment.
} 
depreciations tend to have significantly lower levels of investment. Column 2 shows that firms with higher operating profits after depreciations tend to have significantly higher levels of investment. Column 3 controls for both effects simultaneously. The -2.04 coefficient on leverage implies that when depreciations increase the ratio of debt to assets by 10 percentage points, investment declines by more than $20 \%$. The 0.98 coefficient on the log of operating profits implies that when depreciations increase operating profits by $10 \%$, capital expenditures increase by $9.8 \%$.

Columns 4-6 repeat the specifications from columns 1-3, but allow the coefficients on leverage and/or operating profits to vary across multinational and local firms. The results in column 6 demonstrate that changes in leverage inhibit investment for local firms, but not for multinational affiliates. The effect of operating profits is positive and significant for local firms, and is statistically indistinguishable for multinational affiliates. Results are similar if we scale capital expenditures by end-ofperiod net property, plant and equipment, or if we use operating profitability instead of operating profits. These results provide further support for the implications of the previous analysis. Both multinational affiliates and local firms receive competitiveness benefits after depreciations. These benefits motivate increases in investment, but leverage constrains the ability of local firms (but not multinational affiliates) to take advantage of these benefits and actually increase investment.

\subsection{Robustness Checks}

This evidence that multinational firms expand output after depreciations while local firms contract may reflect unobserved differences in investment opportunities between local firms and multinational affiliates, rather than the differential impact of financial constraints. This could occur, for example, if multinational affiliates are better able to take advantage of the depreciation because they tend to be more oriented to exports. Similarly, if the local economy contracts and local firms are more directly tied to local demand conditions, then the differential response of local firms might simply reflect this differential set of investment opportunities. These alternative explanations, however, are not consistent with the evidence presented above showing similar changes in operating profits for local firms and multinational affiliates. The similar coefficients 
on operating profits and the distinct coefficients on leverage changes in the instrumental variables analysis also are not consistent with these alternative explanations.

Nonetheless, this section conducts additional tests that provide more evidence that these alternative explanations are not driving our results.

The most direct test involves isolating those multinational affiliates that serve only local markets throughout the sample period and comparing those affiliates with local firms. ${ }^{27}$ Restricting the multinational affiliate sample in this way has the advantage of isolating more cleanly multinational affiliates that are tied to local market conditions. The evidence indicates that these locally-focused affiliates increase investment more than local firms during and after currency crises. In addition, we repeat the analysis in Tables 3 through 6 using country/industry/year fixed effects rather than industry/year fixed effects in order to more precisely control for country-specific changes in investment opportunities. ${ }^{28}$ The results on the differential effects of depreciations are robust to these alternative controls which also control for local economic growth. This series of tests suggests that distinctive changes in investment opportunities for the two types of firms do not account for the differential performance of local firms and multinational affiliates.

It is also possible that the relative performance of multinational affiliates and local firms reflects other factors associated with the two types of firms. First, the differential response of multinational firms could reflect over-investment by multinational firms in the aftermath of currency crises rather than constrained under-investment by local firms. In this case, the operating profitability of affiliates would likely fall relative to the operating profitability of local firms. This does not appear to be the case, however, through the sample period. It is also possible that reduced investment by local firms reflects the corporate governance deficiencies of local firms. Johnson et al. (2000) model this possibility and, in their model, stealing increases as investment becomes less profitable through the crisis. We find that investment opportunities improve for the firms in our sample during the currency crises, however, so governance problems as modeled

\footnotetext{
${ }^{27}$ The degree to which firms export or serve the local markets is only available for the multinational affiliates. If some local firms export, than this comparison between fully locally-focused multinational affiliates and local firms should be expected to show local firms outperforming multinational firms if distinctive investment opportunities associated with the export sector are driving the results.

${ }^{28}$ Specifications that employ country/industry/year controls use more aggregated definitions of industries in order to obviate computational constraints.
} 
by Johnson et al. (2000) are unlikely to be driving our results. Although it is difficult to completely reject these alternative possibilities, our robustness tests and the links between changes in leverage and investment in the instrumental variables analysis suggest that it is primarily the impact of financial constraints that explain the differential investment responses documented above.

\section{The Financing of Multinational Affiliates During Currency Crises}

While more granular data on local firms is not available, a closer look at the behavior of multinational affiliates provides further evidence on precisely how they circumvent financing constraints. Table 7 presents regressions that examine growth in different components of affiliate financing subsequent to depreciations. The results in columns 1-3 demonstrate that local debt, foreign debt (debt borrowed from non-local persons), and related party debt (debt borrowed from an affiliate's parent) all increase significantly in the year of depreciations. There are two interpretations of these results. First, new capital may flow to affiliates in one of these forms of debt. Second, if debt is denominated in foreign currency, then the reported increase in debt may simply reflect a revaluation of existing loans to reflect the depreciation. This revaluation of existing debt would not necessarily include any new flows of capital. Since increases in debt occur in the year of depreciations and are larger for debt from foreign sources (which is more likely to be denominated in foreign currency), this revaluation effect may explain at least some part of the growth in debt to multinational affiliates.

Examining changes in paid-in-capital provides cleaner measures of new capital infusions from the parents of affiliates. Paid-in-capital consists of the initial capital stock of an affiliate and any new equity infusions. This measure does not include retained earnings. Since this component of financing is measured in dollars, using historic exchange rates for translation when necessary, changes in the growth of paid-in-capital cannot be explained by changes in currency valuations.

Column 4 of Table 7 reports regression results where the dependent variable is the growth in paid-in-capital. The paid-in-capital of multinational affiliates increases in the years following depreciations, although this increase is only significant in the year after a depreciation. The coefficient estimates suggest that the paid-in-capital of multinational 
affiliates increases by $10.8 \%$ in the year after depreciations. This result provides direct evidence that new equity infusions from parent companies enable multinational affiliates in emerging markets to capitalize on investment opportunities after depreciations. In combination with the evidence provided on changes in leverage and its role in influencing investment, this evidence further confirms the role of internal capital markets in allowing multinational firms to overcome financial constraints that handicap local firms.

\section{Conclusion}

This paper provides evidence on the effects of financial constraints on firm growth by examining the differential performance of multinational affiliates and local firms during currency crises in emerging markets. Affiliates of multinational firms expand sales, assets and investment subsequent to depreciations, while local firms show little change (or a decrease) in each of these measures of operating activity. Local firms and multinational affiliates experience similar changes in operating profits after currency crises, indicating that the competitiveness benefits from depreciations are similar for the two types of firms. Local firms, but not multinational affiliates, tend to experience large increases in leverage, indicating that local firms are more vulnerable to financing constraints after depreciations. Investment specifications that employ depreciation dummies as instruments demonstrate that changes in local firm financial constraints induced by depreciations cause the different investment performance of local firms relative to multinational affiliates. A more detailed analysis of multinational affiliates also demonstrates that multinationals receive equity infusions from their parent companies after depreciations. This evidence further confirms the importance of internal capital markets to multinationals in overcoming the financing constraints that hinder local firms in the aftermath of currency crises.

These findings point to an underappreciated effect of foreign direct investment in emerging markets. The internal capital markets of multinational firms allow their affiliates to expand output after severe depreciations, precisely when economies are fragile and prone to severe economic contractions. As a consequence, multinational affiliates can mitigate some of the aggregate effects of currency crises. This analysis, 
however, does not explore the long-run distributional consequences of this differential impact of currency crises on multinational affiliates. Does increased economic activity due to multinationals during crises help support local firms through spillover effects such as increased demand for local inputs, improved access to trade credit, or higher levels of employment? Or does increased multinational investment crowd out activity by local firms, with potentially persistent effects? While multinational firms appear to mitigate the contractionary output effects of severe depreciations, the longer term effects on local firms remain an open question. 


\section{References}

Agénor, Pierre-Richard and Peter Montiel. (1996). Development Macroeconomics. Princeton, NJ: Princeton University Press.

Aghion, Philippe, Philippe Bachetta and Abhijit Banerjee. (2001). "Currency Crises and Monetary Policy in an Economy with Credit Constraints.” European Economic Review 45:1121-1150.

Aitken, Brian, and Ann E. Harrison. (1999). "Do Domestic Firms Benefit from Direct Foreign Investment? Evidence from Venezuela.” American Economic Review 89:605618.

Aguiar, Mark. (2002). “Investment, Devaluation, and Foreign Currency Exposure: The Case of Mexico.” University of Chicago, Working Paper.

Aguiar, Mark and Gita Gopinath. (2003). “Fire-Sale FDI.” University of Chicago, Working Paper.

Allayannis, George, Gregory W. Brown, and Leora F. Klapper (2003). Capital structure and financial risk: Evidence from foreign debt use in East Asia, Journal of Finance, 58:2667-2710.

Beck, Thorsten, Asli Demirguc-Kunt, and Ross Levine. (2003). "Bank Concentration and Crises.” NBER Working Paper No. 9921.

Bekaert, Geert and Campbell R. Harvey. (2000). "Foreign Speculators and Emerging Equity Markets.” Journal of Finance 55:565-613.

Bernanke, Benjamin and Mark Gertler. (1989). “Agency Costs, Net Worth, and Business Fluctuations.” American Economic Review 79:14-31.

Bertrand, Marianne, Esther Duflo, and Sendhil Mullainathan. (2004). "How Much Should We Trust Differences-in-Differences Estimates.” Quarterly Journal of Economics, forthcoming.

Bleakley, Hoyt and Kevin Cowan. (2002). “Corporate Dollar Debt and Devaluations: Much Ado About Nothing?” University of Chicago and Federal Reserve Bank of Boston, Working Paper.

Blonigen, Bruce. (1997). "Firm-Specific Assets and the Link Between Exchange Rates and Foreign Direct Investment." American Economic Review 87:447-465.

Bris, Arturo and Yrjö Koskinen. (2002). “Corporate Leverage and Currency Crises.” Journal of Financial Economics 63:275-310. 
Caballero, Ricardo J. and Arvind Krishnamurthy. (2001). "International and Domestic Collateral Constraints in a Model of Emerging Market Crises.” Journal of Monetary Economics 48:513-548.

Caballero, Ricardo J. and Arvind Krishnamurthy. (2003). “Excessive Dollar Debt: Financial Development and Underinsurance.” Journal of Finance 58:867-893.

Calvo, Guillermo and Carmen Reinhart. (2000). “Fixing for your Life.” NBER Working Paper No. 8006.

Caprio, Gerard, Jr., and Daniela Klingebiel. (1999). "Episodes of Systematic and Borderline Financial Distress.” The World Bank, Working Paper.

Chevalier, Judith A. (1995) “Capital Structure and Product Market Competition: Empirical Evidence from the Supermarket Industry” American Economic Review 85: 415-435.

Desai, Mihir A., C. Fritz Foley and James R. Hines Jr. (2003). “A Multinational Perspective on Capital Structure Choice and Internal Capital Markets.” Journal of Finance, forthcoming.

Desai, Mihir A., C. Fritz Foley and James R. Hines Jr. (2004). “Capital Controls, Liberalizations, and Foreign Direct Investment.” NBER Working Paper No. 10337.

Edwards, Sebastian. (1989). Real Exchange Rates, Devaluation and Adjustment. Cambridge, MA: MIT Press.

Eskeland, Gunnar S., and Ann E. Harrison. (2003). "Moving to Greener Pastures? Multinationals and the Pollution Haven Hypothesis.” Journal of Development Economics, forthcoming.

Evans, David S. (1987a). “The Relationship Between Firm Growth, Size, and Age: Estimates for 100 Manufacturing Industries.” Journal of Industrial Economics 35:567581.

Evans, David S. (1987b). “Tests of Alternative Theories of Firm Growth.” Journal of Political Economy 95:657-674.

Fazzari, Steven M., R. Glenn Hubbard and Bruce C. Petersen. (1988) "Financing Constraints and Corporate Investment," Brookings Papers on Economic Activity, 141195.

Fazzari, Steven M., R. Glenn Hubbard and Bruce C. Petersen. (2000) "Investment-Cash Flow Sensitivities Are Useful,” Quarterly Journal of Economics, 115:695-705.

Figlio, David N. and Bruce A. Blonigen. (2000). "The Effects of Foreign Direct Investment on Local Communities.” Journal of Urban Economics 48:338-363. 
Forbes, Kristin J. (2002a). “Cheap Labor Meets Costly Capital: The Impact of Devaluations on Commodity Firms.” Journal of Development Economics 69:35-365.

Forbes, Kristin J. (2002b). "How do Large Depreciations Affect Firm Performance?” IMF Staff Papers 49:214-238.

Froot, Kenneth and Jeremy Stein. (1991). "Exchange Rates and Foreign Direct Investment: An Imperfect Capital Markets Approach.” Quarterly Journal of Economics 106:1191-1217.

Goldberg, Pinelopi and Michael Knetter. (1997). "Goods Prices and Exchange Rates: What Have We Learned?” Journal of Economic Literature 35:273-296.

Gupta, Poonam, Deepak Mishra and Ratna Sahay. (2000). “Output Response During Currency Crises.” IMF, Working Paper.

Harrison, Ann E., and Margaret S. McMillan. (2003). "Does Direct Foreign Investment Affect Domestic Firms Credit Constraints?” Journal of International Economics, forthcoming.

Hall, Bronwyn H. (1987). "The Relationship Between Firm Size and Firm Growth in the US Manufacturing Sector.” Journal of Industrial Economics 35:583-606.

Hennessy, Christopher A. (2003). “Tobin’s Q, Debt Overhang, and Investment.” Journal of Finance, forthcoming.

Henry, Peter Blair. (2000a). "Stock Market Liberalization, Economic Reform, and Emerging Market Equity Prices.” Journal of Finance 55:529-564.

Henry, Peter Blair. (2000b). "Do Stock Market Liberalizations Cause Investment Booms?” Journal of Financial Economics 58:301-334.

Hubbard, R. Glenn. (1998). “Capital Market Imperfections and Investment.” Journal of Economic Literature 36:193-225.

International Monetary Fund. (2003). International Financial Statistics. Database on CDROM. March.

Johnson, Simon, Peter Boone, Alasdair Breach and Eric Friedman. (2000). "Corporate Governance in the Asian Financial Crisis.” Journal of Financial Economics 58:141-186.

Kaplan, Steven N. and Luigi Zingales. (1997) "Do Investment-Cash Flow Sensitivities Provide Useful Measures of Financing Constraints,” Quarterly Journal of Economics, 112:169-215.

Kaplan, Steven N. and Luigi Zingales. (2000) "Investment-Cash Flow Sensitivities Are Not Valid Measures of Financing Constraints," Quarterly Journal of Economics, 115:707-712. 
Krueger, Anne and Aaron Tornell. (1999). "The Role of Bank Restructuring in Recovering from Crises: Mexico 1995-1998.” NBER Working Paper No. 7042.

Lamont, Owen (1997). “Cash Flow and Investment: Evidence from Internal Capital Markets.” Journal of Finance 52:83-109.

Lang, Larry, Eli Ofek and René M. Stulz. (1995). “Leverage, Investment and Firm Growth.” Journal of Financial Economics 40:3-29.

Mitton, Todd. (2002). "A Cross-firm Analysis of the Impact of Corporate Governance on the East Asian Financial Crisis.” Journal of Financial Economics 64:215-241.

Myers, Stewart. (1977). “Determinants of Corporate Borrowing.” Journal of Financial Economics 5:147-175.

Peek, Joseph and Eric Rosengren. (1997). “The International Transmission of Financial Shocks: The Case of Japan,” American Economic Review, 87:495-505.

Reif, Tania. (2001). “The ‘Real’ Side of Currency Crises.” Columbia University, Working Paper.

Stein, Jeremy. (2003). “Agency, Information and Corporate Investment,” in George Constantinides, Milt Harris and Rene Stulz (eds.) Handbook of the Economics of Finance New York: Elsevier, 111-165.

Stulz, René. (1999). “Globalization of Equity Markets and the Cost of Capital.” NBER Working Paper No. 7021.

Whited, Toni. (1992). “Debt, Liquidity Constraints, and Corporate Investment: Evidence from Panel Data.” Journal of Finance 47:1425-1461. 


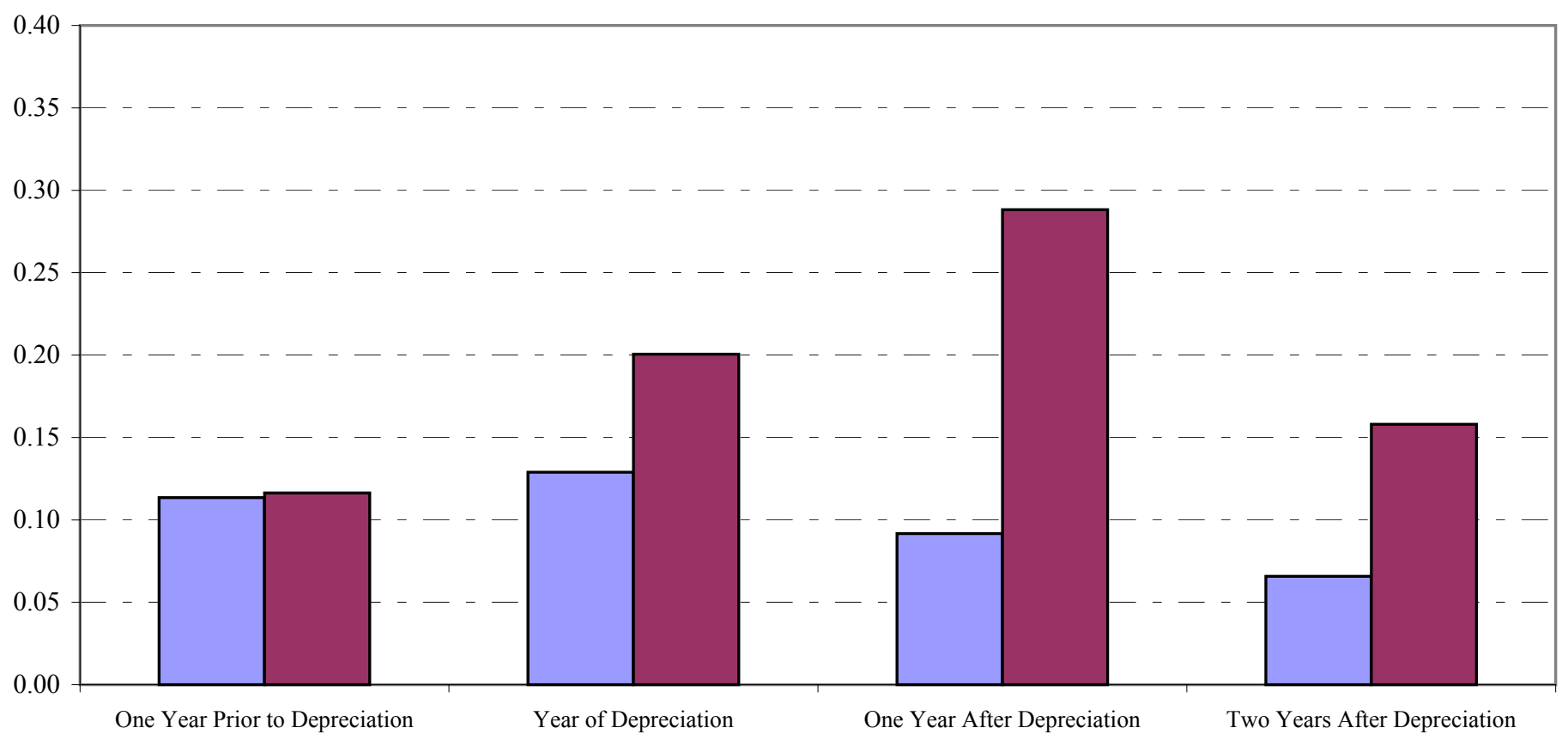

Panel B: Asset Growth

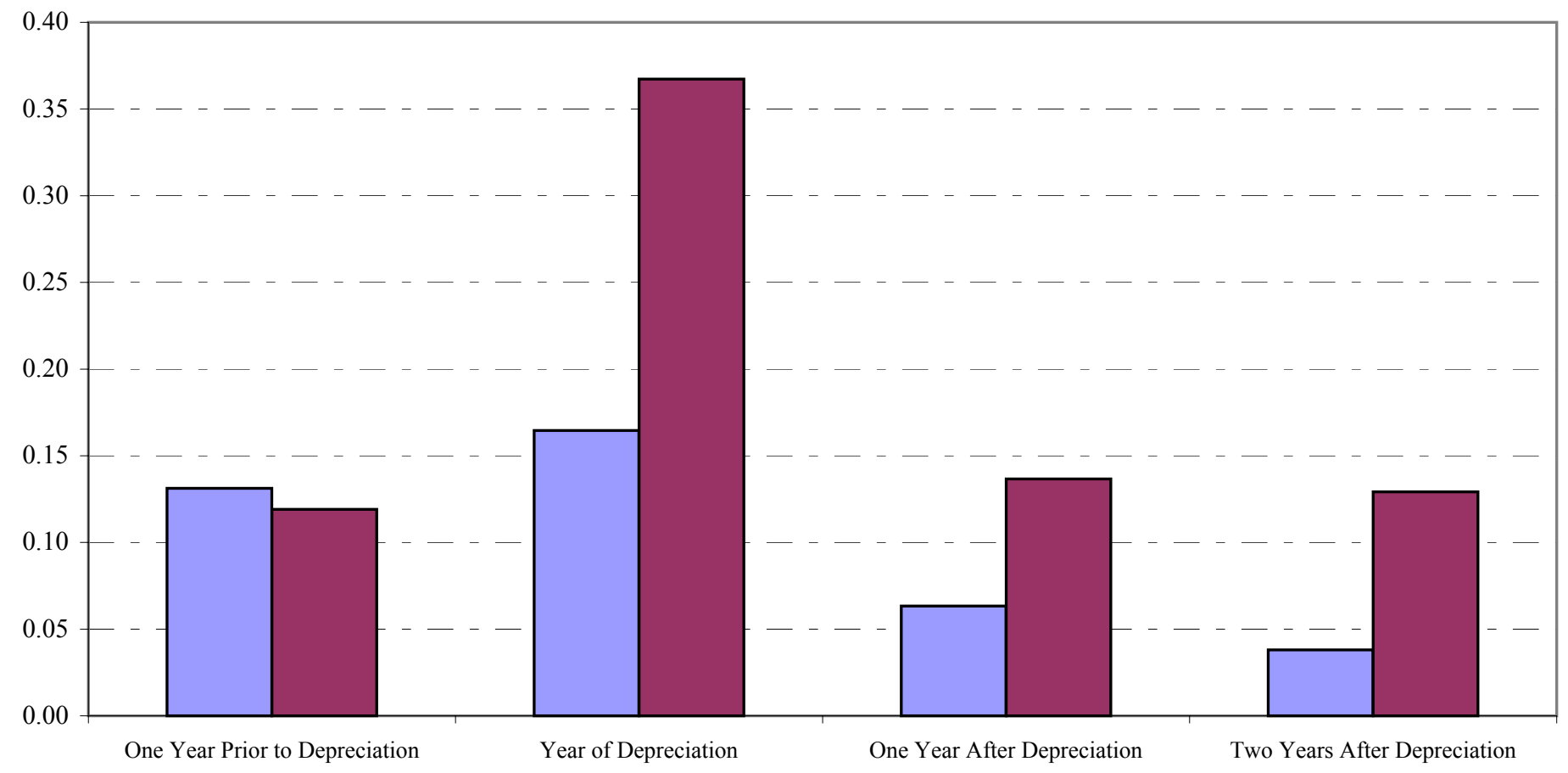

$\square$ Local Firms $\square$ MNC Affiliates

Note: The panels compare the median growth rates of sales and assets of local firms and U.S. multinational affiliates. In each panel, the pairs of bars correspond to years relative to a currency crisis. Within each pair, the first bar represents the median growth rate for local firms and the second bar represents the median growth rate for the multinational affiliates. 
Figure 2: Changes in Leverage and Operating Profitability for U.S. Multinational Affiliates and Local Firms During Currency Crises

Panel A: Leverage

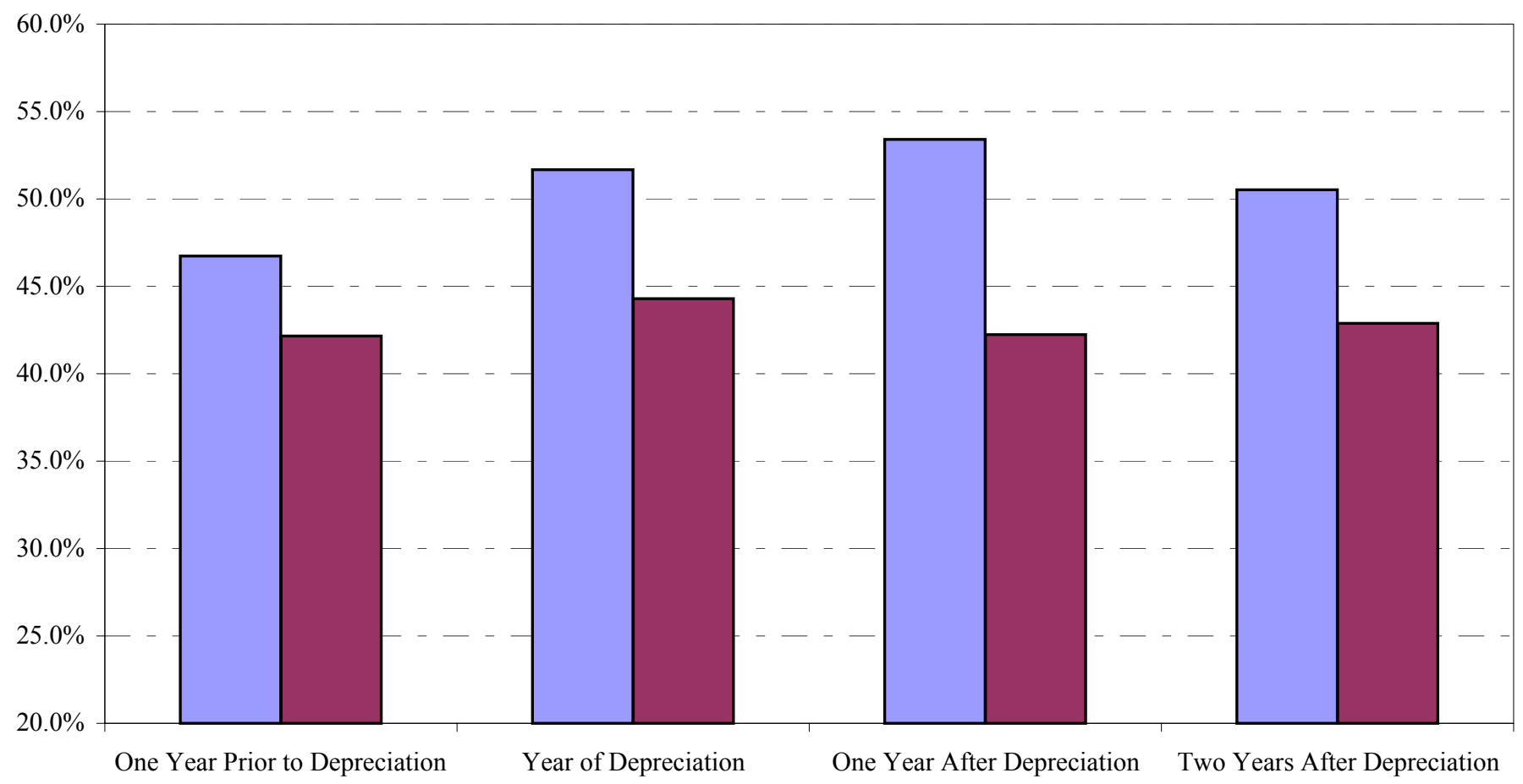

Panel B: Operating Profitability

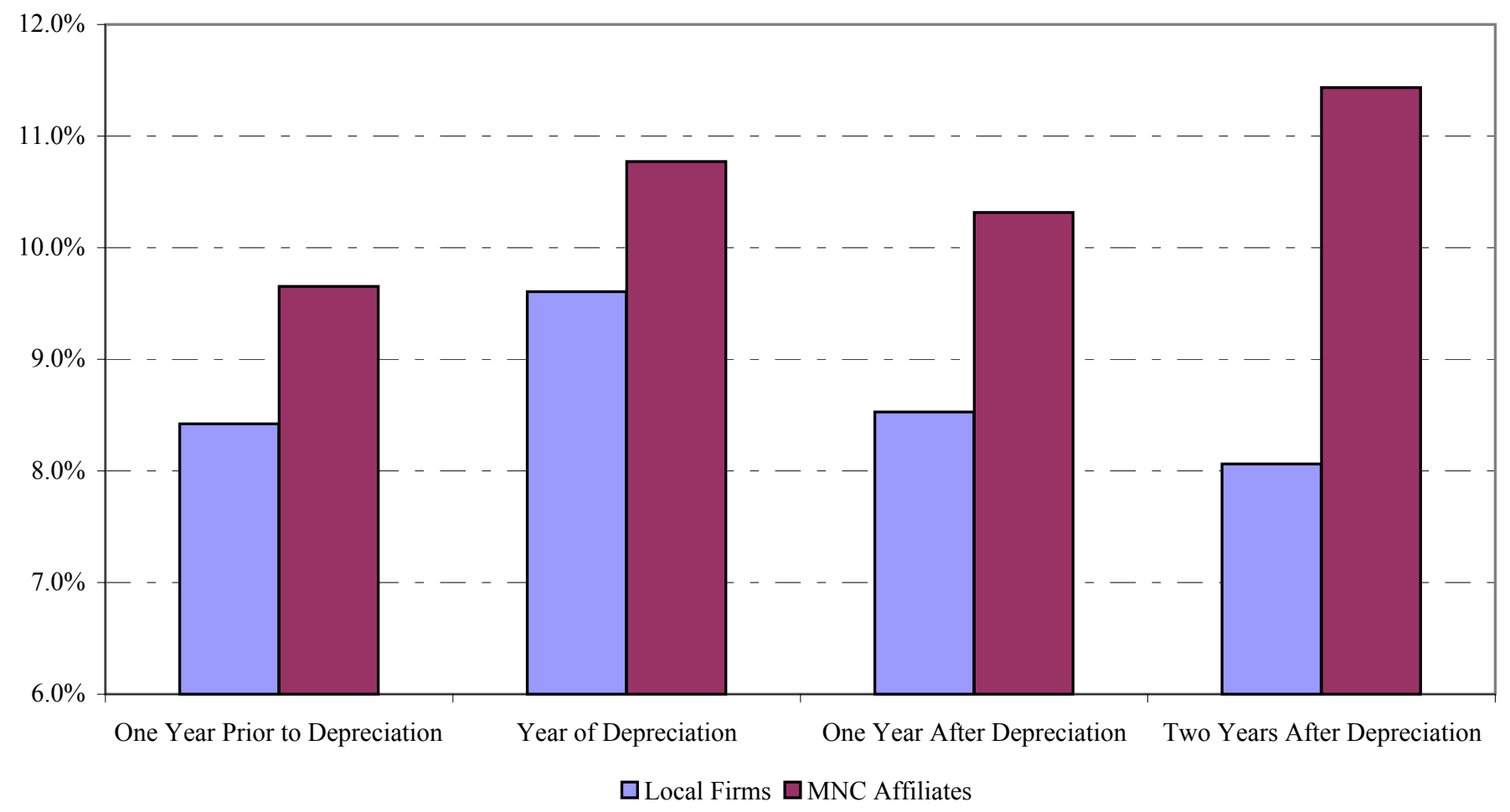

Note: The panels compare the median leverage and the median operating profitability of local firms and U.S. multinational affiliates. In each panel the pairs of bars correspond to years relative to a currency crisis. Within each pair, the first bar represents the median value for local firms and the second bar represents the median value for the multinational affiliates. 
Table 1

Sample Composition by Year and by Type of Firm for Emerging Markets with Currency Crises and Control Countries

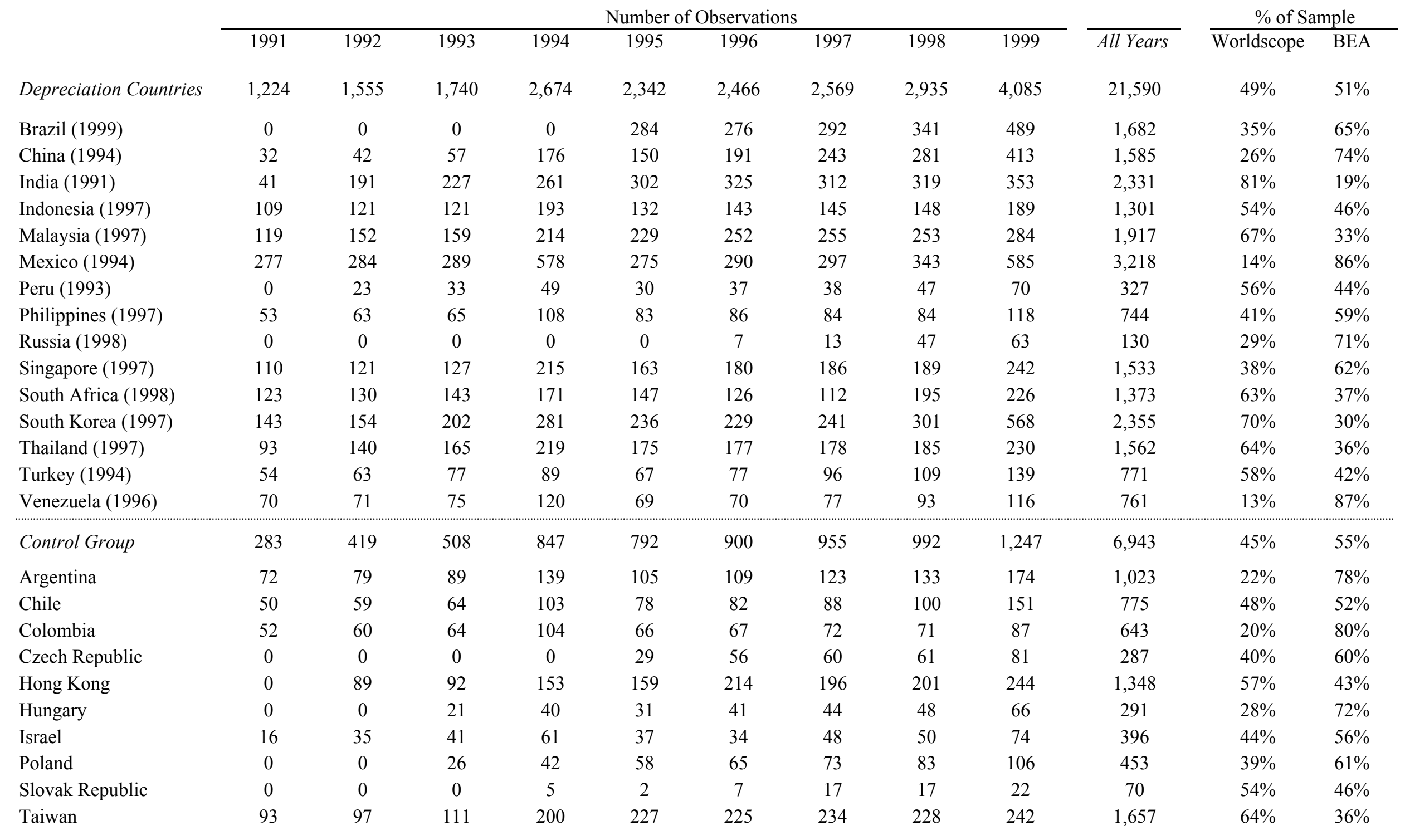

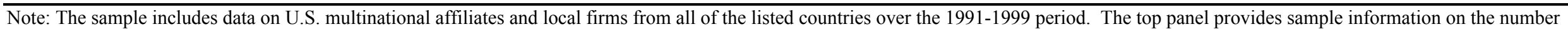

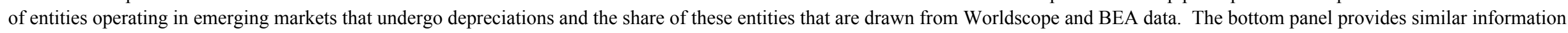

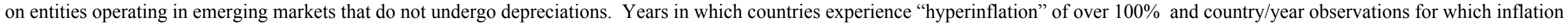

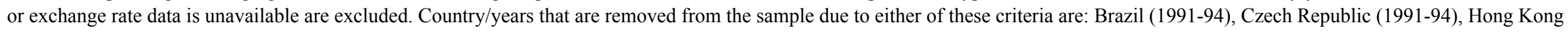

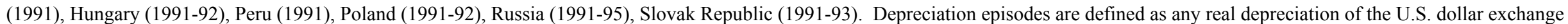

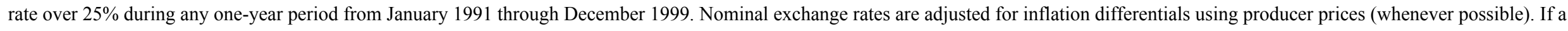
country experiences a depreciation episode in the current year, the next year is excluded as a possible episode. 
Table 2

Descriptive Statistics for Local Firms and Multinational Affiliates

Log of Sales

Sales Growth

Log of Assets

Asset Growth

Log of Capital Expenditures

Capital Expenditures/ Net PPE

Log of Operating Profits

Operating Profitability

Leverage

Price Index

Inflation

Growth in Local Debt

Growth in Foreign Debt

Growth in Related Party Debt

Growth in Paid in Capital

\begin{tabular}{ccc}
\multicolumn{3}{c}{ Local Firms } \\
\hline \multirow{3}{*}{ Mean } & Standard \\
Deviation $\quad$ Median \\
\hline
\end{tabular}

15.0488

3.0231

0.1266

0.3144

15.4664

2.9699

0.1460

0.2448

12.4075

3.1360

0.1967

0.1697

13.0989

3.1087

0.0939

0.1629

0.4730

0.2307

0.4617

115.3496

75.1014

103.2000

0.0796

0.1272

0.0459

12.0052

0.1522

12.4497

\begin{tabular}{cc}
\multicolumn{3}{c}{ Multinational Affiliates } \\
\hline Standard \\
Mean & Deviation $\quad$ Median \\
\hline
\end{tabular}

13.3198

2.9091

12.8418

0.1969

0.3759

0.1494

$13.5045 \quad 2.7861$

12.8514

0.1689

0.2958

0.1405

10.2501

3.0486

9.7854

0.2303

0.2259

0.1696

12.0271

2.9005

11.4914

0.1201

0.1699

0.1083

0.4559

0.2672

0.4168

115.8554

67.7326

100.0000

0.1082

0.1434

0.0656

0.1401

0.6110

0.1291

0.1228

0.7418

0.0690

0.0852

0.8119

0.0000

0.0624

0.3446

0.0000

Note: Values of sales, assets, capital expenditures, net PPE, operating revenues, local sales, foreign sales, related party sales, local debt, foreign debt, and related party debt are measured in thousands of local currency units. The growth rates are calculated as differences in log values. Operating profits are the difference between sales and operating expenses. Operating Profitability is the ratio of the difference between sales and operating expenses to sales. Leverage is the ratio of debt to assets. The price index and inflation are taken from Datastream and measure prices and changes in prices in the host country. Local debt is borrowing by an affiliate from persons in the affiliate's host country. Foreign debt is borrowing by an affiliate from person's outside the affiliate's host country. Related party debt is borrowing by an affiliate from the affiliate's parent. Paid in capital includes equity capital investments in an affiliate, and this item is measured in U.S. dollars. 
Table 3

Responses of Multinationals and Local Firms to Currency Crises

\begin{tabular}{|c|c|c|c|c|c|c|c|c|}
\hline \multirow[t]{2}{*}{ Dependent Variable: } & \multicolumn{2}{|c|}{ Log of Sales } & \multicolumn{2}{|c|}{ Sales Growth } & \multicolumn{2}{|c|}{ Log of Assets } & \multicolumn{2}{|c|}{ Asset Growth } \\
\hline & (1) & $(2)$ & (3) & (4) & (5) & (6) & (7) & (8) \\
\hline Constant & $\begin{array}{r}12.8621 \\
(0.6518)\end{array}$ & $\begin{array}{r}12.8581 \\
(0.6531)\end{array}$ & $\begin{array}{r}1.3997 \\
(0.4276)\end{array}$ & $\begin{array}{r}1.4149 \\
(0.4269)\end{array}$ & $\begin{array}{c}12.8046 \\
(0.7287)\end{array}$ & $\begin{array}{r}12.8235 \\
(0.7511)\end{array}$ & $\begin{array}{r}2.8180 \\
(0.3849)\end{array}$ & $\begin{array}{r}2.9006 \\
(0.4061)\end{array}$ \\
\hline Price index & $\begin{array}{r}0.0048 \\
(0.0003)\end{array}$ & $\begin{array}{r}0.0049 \\
(0.0003)\end{array}$ & & & $\begin{array}{r}0.0044 \\
(0.0002)\end{array}$ & $\begin{array}{r}0.0043 \\
(0.0002)\end{array}$ & & \\
\hline Inflation & & & $\begin{array}{r}0.7361 \\
(0.0534)\end{array}$ & $\begin{array}{r}0.7236 \\
(0.0528)\end{array}$ & & & $\begin{array}{r}0.2050 \\
(0.0375)\end{array}$ & $\begin{array}{r}0.1456 \\
(0.0374)\end{array}$ \\
\hline Lag of Sales & & & $\begin{array}{r}-0.1419 \\
(0.0200)\end{array}$ & $\begin{array}{r}-0.1424 \\
(0.0200)\end{array}$ & & & & \\
\hline Lag of Assets & & & & & & & $\begin{array}{r}-0.2181 \\
(0.0112)\end{array}$ & $\begin{array}{r}-0.2275 \\
(0.0114)\end{array}$ \\
\hline Depreciation $_{\mathrm{t}-1}$ & $\begin{array}{r}-0.0712 \\
(0.0265)\end{array}$ & $\begin{array}{r}-0.0782 \\
(0.0262)\end{array}$ & $\begin{array}{r}-0.0185 \\
(0.0146)\end{array}$ & $\begin{array}{c}-0.0147 \\
(0.0145)\end{array}$ & $\begin{array}{r}-0.0286 \\
(0.0188)\end{array}$ & $\begin{array}{r}-0.0265 \\
(0.0186)\end{array}$ & $\begin{array}{r}-0.0223 \\
(0.0111)\end{array}$ & $\begin{array}{r}-0.0217 \\
(0.0111)\end{array}$ \\
\hline Depreciation $_{\mathrm{t}}$ & $\begin{array}{r}-0.0437 \\
(0.0283)\end{array}$ & & $\begin{array}{r}-0.0284 \\
(0.0154)\end{array}$ & & $\begin{array}{r}0.0376 \\
(0.0209)\end{array}$ & & $\begin{array}{r}0.0199 \\
(0.0127)\end{array}$ & \\
\hline Depreciation $_{\mathrm{t}+1}$ & $\begin{array}{r}-0.0787 \\
(0.0316)\end{array}$ & & $\begin{array}{r}-0.0845 \\
(0.0179)\end{array}$ & & $\begin{array}{r}-0.0219 \\
(0.0228)\end{array}$ & & $\begin{array}{r}-0.0624 \\
(0.0136)\end{array}$ & \\
\hline Depreciation $_{\mathrm{t}+2}$ & $\begin{array}{r}-0.1270 \\
(0.0327)\end{array}$ & & $\begin{array}{c}-0.0247 \\
(0.0144)\end{array}$ & & $\begin{array}{r}-0.0579 \\
(0.0242)\end{array}$ & & $\begin{array}{r}-0.0499 \\
(0.0114)\end{array}$ & \\
\hline Post Depreciation & & $\begin{array}{r}-0.0852 \\
(0.0272)\end{array}$ & & $\begin{array}{r}-0.0414 \\
(0.0114)\end{array}$ & & $\begin{array}{r}-0.0143 \\
(0.0207)\end{array}$ & & $\begin{array}{r}-0.0266 \\
(0.0098)\end{array}$ \\
\hline $\begin{array}{l}\text { Multinational* }^{*} \\
\text { Depreciation }_{\mathrm{t}-1}\end{array}$ & $\begin{array}{r}0.0073 \\
(0.0404)\end{array}$ & $\begin{array}{r}0.0174 \\
(0.0397)\end{array}$ & $\begin{array}{r}-0.0580 \\
(0.0193)\end{array}$ & $\begin{array}{r}-0.0593 \\
(0.0192)\end{array}$ & $\begin{array}{r}-0.0147 \\
(0.0243)\end{array}$ & $\begin{array}{r}-0.0168 \\
(0.0240)\end{array}$ & $\begin{array}{r}-0.0147 \\
(0.0162)\end{array}$ & $\begin{array}{r}-0.0218 \\
(0.0163)\end{array}$ \\
\hline $\begin{array}{l}\text { Multinational* }^{*} \\
\text { Depreciation }_{\mathrm{t}}\end{array}$ & $\begin{array}{r}-0.0447 \\
(0.0528)\end{array}$ & & $\begin{array}{r}0.0248 \\
(0.0210)\end{array}$ & & $\begin{array}{r}0.1256 \\
(0.0285)\end{array}$ & & $\begin{array}{r}0.1488 \\
(0.0183)\end{array}$ & \\
\hline $\begin{array}{l}\text { Multinational* } \\
\text { Depreciation }_{\mathrm{t}+1}\end{array}$ & $\begin{array}{r}0.1466 \\
(0.0546)\end{array}$ & & $\begin{array}{r}0.1415 \\
(0.0251)\end{array}$ & & $\begin{array}{r}0.1019 \\
(0.0327)\end{array}$ & & $\begin{array}{r}0.0104 \\
(0.0197)\end{array}$ & \\
\hline $\begin{array}{l}\text { Multinational* } \\
\text { Depreciation }_{\mathrm{t}+2}\end{array}$ & $\begin{array}{r}0.1898 \\
(0.0580)\end{array}$ & & $\begin{array}{r}0.0088 \\
(0.0242)\end{array}$ & & $\begin{array}{r}0.0779 \\
(0.0362)\end{array}$ & & $\begin{array}{r}0.0250 \\
(0.0176)\end{array}$ & \\
\hline $\begin{array}{l}\text { Multinational* Post } \\
\text { Depreciation }\end{array}$ & & $\begin{array}{r}0.0841 \\
(0.0456)\end{array}$ & & $\begin{array}{r}0.0544 \\
(0.0158)\end{array}$ & & $\begin{array}{r}0.1130 \\
(0.0278)\end{array}$ & & $\begin{array}{r}0.0753 \\
(0.0136)\end{array}$ \\
\hline $\begin{array}{l}\text { Industry/Year Fixed } \\
\text { Effects? } \\
\text { Firm Fixed Effects? }\end{array}$ & $\begin{array}{l}\mathrm{Y} \\
\mathrm{Y}\end{array}$ & $\begin{array}{l}\mathrm{Y} \\
\mathrm{Y}\end{array}$ & $\begin{array}{l}\mathrm{Y} \\
\mathrm{Y}\end{array}$ & $\begin{array}{l}\mathrm{Y} \\
\mathrm{Y}\end{array}$ & $\begin{array}{l}\mathrm{Y} \\
\mathrm{Y}\end{array}$ & $\begin{array}{l}\mathrm{Y} \\
\mathrm{Y}\end{array}$ & $\begin{array}{l}\mathrm{Y} \\
\mathrm{Y}\end{array}$ & $\begin{array}{l}\mathrm{Y} \\
\mathrm{Y}\end{array}$ \\
\hline $\begin{array}{l}\text { No. of Obs. } \\
\text { R-Squared }\end{array}$ & $\begin{array}{l}27,969 \\
0.9684\end{array}$ & $\begin{array}{l}27,969 \\
0.9683\end{array}$ & $\begin{array}{l}19,627 \\
0.5250\end{array}$ & $\begin{array}{l}19,627 \\
0.5235\end{array}$ & $\begin{array}{l}27,767 \\
0.9898\end{array}$ & $\begin{array}{l}27,767 \\
0.9898\end{array}$ & $\begin{array}{l}19,476 \\
0.5345\end{array}$ & $\begin{array}{l}19,476 \\
0.5221\end{array}$ \\
\hline
\end{tabular}

\footnotetext{
Note: The dependent variable is the logarithm of sales in columns (1) and (2), growth in sales in columns (3) and (4), the logarithm of assets in columns (5) and (6), and growth in assets in columns (7) and (8). The sample used in all specifications includes U.S. multinational and local firms operating in emerging markets. Each specification includes industry/year and firm fixed effects. "Price index" is an index of producer prices (or consumer prices if producer prices are unavailable) in the host country; the base year of 1995 has a price index of 100. "Inflation" is the change in the producer price index over the period. Changes in consumer price indices are used if changes in producer price indices are not available. "Lag of Sales" is the log of sales in the previous period, and "Lag of Assets" is the log of beginning of period assets. The time sub-scripted "Depreciation" variables are a set of dummies equal to one in the year prior to, the year of, and the two years following a depreciation. "Post Depreciation" is a dummy equal to one in the year of and the two years following a depreciation. "Multinational" is a dummy set equal to one for affiliates of U.S. multinationals. Heteroskedasticity-consistent standard errors that correct for clustering of errors by firm appear in parentheses.
} 
Table 4

Investment Responses of Multinationals and Local Firms to Currency Crises

\begin{tabular}{|c|c|c|c|c|}
\hline Dependent Variable: & $\begin{array}{c}\text { Log of Capital } \\
\text { Expenditures }\end{array}$ & $\begin{array}{c}\text { Log of Capital } \\
\text { Expenditures }\end{array}$ & $\begin{array}{c}\text { Capital } \\
\text { Expenditures/ } \\
\text { Net PPE }\end{array}$ & $\begin{array}{c}\text { Capital } \\
\text { Expenditures/ } \\
\text { Net PPE }\end{array}$ \\
\hline & (1) & $(2)$ & (3) & (4) \\
\hline Constant & $\begin{array}{r}7.5609 \\
(0.9240)\end{array}$ & $\begin{array}{r}7.6623 \\
(0.9401)\end{array}$ & $\begin{array}{r}0.2267 \\
(0.2081)\end{array}$ & $\begin{array}{r}0.2228 \\
(0.2162)\end{array}$ \\
\hline Price Index & $\begin{array}{r}0.0048 \\
(0.0004)\end{array}$ & $\begin{array}{r}0.0047 \\
(0.0004)\end{array}$ & $\begin{array}{r}0.0001 \\
(0.0000)\end{array}$ & $\begin{array}{r}0.0001 \\
(0.0000)\end{array}$ \\
\hline Depreciation $_{\mathrm{t}-1}$ & $\begin{array}{r}0.0362 \\
(0.0522)\end{array}$ & $\begin{array}{r}0.0253 \\
(0.0518)\end{array}$ & $\begin{array}{r}0.0122 \\
(0.0074)\end{array}$ & $\begin{array}{r}0.0103 \\
(0.0073)\end{array}$ \\
\hline Depreciation $_{t}$ & $\begin{array}{r}0.0650 \\
(0.0570)\end{array}$ & & $\begin{array}{r}0.0070 \\
(0.0072)\end{array}$ & \\
\hline Depreciation $_{t+1}$ & $\begin{array}{r}-0.2820 \\
(0.0604)\end{array}$ & & $\begin{array}{r}-0.0326 \\
(0.0073)\end{array}$ & \\
\hline Depreciation $_{\mathrm{t}+2}$ & $\begin{array}{r}-0.3942 \\
(0.0625)\end{array}$ & & $\begin{array}{r}-0.0373 \\
(0.0071)\end{array}$ & \\
\hline Post Depreciation & & $\begin{array}{r}-0.2101 \\
(0.0506)\end{array}$ & & $\begin{array}{r}-0.0220 \\
(0.0058)\end{array}$ \\
\hline Multinational*Depreciation $_{\mathrm{t}-1}$ & $\begin{array}{r}-0.0173 \\
(0.0719)\end{array}$ & $\begin{array}{r}-0.0011 \\
(0.0711)\end{array}$ & $\begin{array}{r}-0.0031 \\
(0.0111)\end{array}$ & $\begin{array}{r}-0.0003 \\
(0.0110)\end{array}$ \\
\hline Multinational*Depreciation $_{\mathrm{t}}$ & $\begin{array}{r}0.0790 \\
(0.0797)\end{array}$ & & $\begin{array}{r}-0.0215 \\
(0.0116)\end{array}$ & \\
\hline Multinational*Depreciation $_{\mathrm{t}+1}$ & $\begin{array}{r}0.5311 \\
(0.0887)\end{array}$ & & $\begin{array}{r}0.0619 \\
(0.0136)\end{array}$ & \\
\hline Multinational*Depreciation $_{\mathrm{t}+2}$ & $\begin{array}{r}0.4133 \\
(0.0934)\end{array}$ & & $\begin{array}{r}0.0460 \\
(0.0122)\end{array}$ & \\
\hline Multinational*Post Depreciation & & $\begin{array}{r}0.3448 \\
(0.0700)\end{array}$ & & $\begin{array}{r}0.0257 \\
(0.0095)\end{array}$ \\
\hline Industry/Year Fixed Effects? & $\mathrm{Y}$ & $\mathrm{Y}$ & $\mathrm{Y}$ & $\mathrm{Y}$ \\
\hline Firm Fixed Effects? & $\mathrm{Y}$ & $\mathrm{Y}$ & $\mathrm{Y}$ & $\mathrm{Y}$ \\
\hline No. of Obs. & 23,950 & 23,950 & 25,524 & 25,524 \\
\hline R-Squared & 0.9382 & 0.9379 & 0.5817 & 0.5801 \\
\hline
\end{tabular}

Note: The dependent variable in columns (1) and (2) is the log of capital expenditures, and the dependent variable in columns (3) and (4) is capital expenditures scaled by net property, plant, and equipment. The sample used in all specifications includes U.S. multinational and local firms operating in emerging markets. Each specification includes industry/year and firm fixed effects. "Price index" is an index of producer prices (or consumer prices if producer prices are unavailable) in the host country; the base year of 1995 has a price index of 100 . The time sub-scripted "Depreciation" variables are a set of dummies equal to one in the year prior to, the year of, and the two years following a depreciation. "Post Depreciation" is a dummy equal to one in the year of and the two years following a depreciation. "Multinational" is a dummy set equal to one for affiliates of U.S. multinationals. Heteroskedasticity-consistent standard errors that correct for clustering of errors by firm appear in parentheses. 
Table 5

The Determinants of Investment Responses

Dependent Variable:

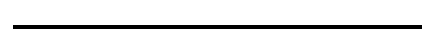

$\begin{array}{lr}\text { Constant } & 14.2066 \\ & (0.5273) \\ \text { Price Index } & 0.0043 \\ & (0.0004) \\ \text { Depreciation }_{\mathrm{t}-1} & -0.0953 \\ & (0.0453) \\ \text { Depreciation }_{\mathrm{t}} & 0.0790 \\ & (0.0452) \\ \text { Depreciation }_{\mathrm{t}+1} & 0.0035 \\ & (0.0453) \\ \text { Depreciation }_{\mathrm{t}+2} & 0.0315 \\ & (0.0434)\end{array}$

Post Depreciation

Multinational*

Depreciation $_{\mathrm{t}-1}$

$-0.0029$

(0.0654)

Multinational*

$-0.0256$

Depreciation $_{\mathrm{t}}$

Multinational*

(0.0713)

0.0684

Depreciation $_{\mathrm{t}+1}$

Multinational*

0.1292

Depreciation $_{\mathrm{t}+2}$

(0.0840)

Multinational* Post

Depreciation

Industry/Year Fixed

Effects?

Firm Fixed Effects?

No. of Obs.

R-Squared

\begin{tabular}{|c|c|}
\hline & $\begin{array}{r}0.0505 \\
(0.0602)\end{array}$ \\
\hline Y & $\mathrm{Y}$ \\
\hline $\mathrm{Y}$ & $\mathrm{Y}$ \\
\hline 16,562 & 16,562 \\
\hline 0.9648 & 0.9647 \\
\hline
\end{tabular}

Leverage

(3)

(4)

14.1739

(0.5251)

0.0043

(0.0004)

$-0.1026$

(0.0444)

$-0.0616$

$-0.0575$

(0.2092)

(0.2132)

0.0001

0.0001

(0.0000)

(0.0000)

0.0240

0.0245

(0.0056)

(0.0056)

0.0753

(0.0068)

0.0825

(0.0082)

0.0521

(0.0092)

0.0703

(0.0068)

(0.0348)

0.0056

(0.0643)

$-0.0311$

$-0.0312$

(0.0104)

(0.0102)

$-0.0750$

(0.0134)

$-0.1118$

(0.0154)

$-0.0812$

(0.0167)

$-0.0865$

(0.0120)

Y

$\mathrm{Y}$

Y

$\mathrm{Y}$

19,642

19,642

0.7926

0.7921

Note: The dependent variable is the log of operating revenues in columns (1) and (2), operating profitability in columns (3) and (4), and leverage in columns (5) and (6). Operating profits are equal to sales less operating expenses, and operating profitability is the ratio of operating profits to sales. Leverage is measured as the ratio of current liabilites and long term debt to assets. The sample used in all specifications includes U.S. multinational and local firms operating in emerging markets. Each specification includes industry/year and firm fixed effects. "Price index" is an index of producer prices (or consumer prices if producer prices are unavailable) in the host country; the base year of 1995 has a price index of 100. The time sub-scripted "Depreciation" variables are a set of dummies equal to one in the year prior to, the year of, and the two years following a depreciation. "Post Depreciation" is a dummy equal to one in the year of and the two years following a depreciation. "Multinational" is a dummy set equal to one for affiliates of U.S. multinationals. Heteroskedasticity-consistent standard errors that correct for clustering of errors by firm appear in parentheses. 
Table 6

Instrumental Variables Analysis of the Determinants of Investment Responses

Dependent Variable:

Log Capital Expenditures

\begin{tabular}{|c|c|c|c|c|c|c|}
\hline & (1) & $(2)$ & (3) & (4) & (5) & (6) \\
\hline Constant & $\begin{array}{l}12.1656 \\
(1.3820)\end{array}$ & $\begin{array}{r}1.3634 \\
(3.5442)\end{array}$ & $\begin{array}{r}-1.7350 \\
(4.6111)\end{array}$ & $\begin{array}{l}11.9299 \\
(1.5090)\end{array}$ & $\begin{array}{r}3.4188 \\
(3.5846)\end{array}$ & $\begin{array}{r}-1.4944 \\
(5.5624)\end{array}$ \\
\hline Leverage & $\begin{array}{r}-2.5728 \\
(0.3989)\end{array}$ & & $\begin{array}{r}-2.0398 \\
(0.5254)\end{array}$ & $\begin{array}{r}-2.5126 \\
(0.4292)\end{array}$ & & $\begin{array}{r}-2.3131 \\
(0.7461)\end{array}$ \\
\hline Multinational * Leverage & & & & $\begin{array}{r}-1.0830 \\
(2.5082)\end{array}$ & & $\begin{array}{r}9.1130 \\
(4.2359)\end{array}$ \\
\hline Log Operating Profits & & $\begin{array}{r}0.7352 \\
(0.2667)\end{array}$ & $\begin{array}{r}0.9847 \\
(0.3139)\end{array}$ & & $\begin{array}{r}0.4556 \\
(0.2923)\end{array}$ & $\begin{array}{r}1.0366 \\
(0.4492)\end{array}$ \\
\hline $\begin{array}{l}\text { Multinational * Log Operating } \\
\text { Profits }\end{array}$ & & & & & $\begin{array}{r}0.3670 \\
(0.1770)\end{array}$ & $\begin{array}{r}0.1467 \\
(0.3158)\end{array}$ \\
\hline Price Index & $\begin{array}{r}0.0049 \\
(0.0003)\end{array}$ & $\begin{array}{r}0.0003 \\
(0.0015)\end{array}$ & $\begin{array}{r}-0.0008 \\
(0.0018)\end{array}$ & $\begin{array}{r}0.0049 \\
(0.0003)\end{array}$ & $\begin{array}{r}0.0007 \\
(0.0015)\end{array}$ & $\begin{array}{r}-0.0015 \\
(0.0021)\end{array}$ \\
\hline $\begin{array}{l}\text { IV using Depreciation } \\
\text { Episodes? } \\
\text { Industry/Year Fixed Effects? } \\
\text { Firm Fixed Effects? }\end{array}$ & $\begin{array}{l}\mathrm{Y} \\
\mathrm{Y} \\
\mathrm{Y}\end{array}$ & $\begin{array}{l}\mathrm{Y} \\
\mathrm{Y} \\
\mathrm{Y}\end{array}$ & $\begin{array}{l}\mathrm{Y} \\
\mathrm{Y} \\
\mathrm{Y}\end{array}$ & $\begin{array}{l}\mathrm{Y} \\
\mathrm{Y} \\
\mathrm{Y}\end{array}$ & $\begin{array}{l}\mathrm{Y} \\
\mathrm{Y} \\
\mathrm{Y}\end{array}$ & $\begin{array}{l}\mathrm{Y} \\
\mathrm{Y} \\
\mathrm{Y}\end{array}$ \\
\hline No. of Obs. & 18,089 & 15,470 & 15,223 & 18,089 & 15,470 & 15,223 \\
\hline
\end{tabular}


Table 7

Financing Responses of Multinationals to Currency Crises

\begin{tabular}{|c|c|c|c|c|}
\hline Dependent Variable: & $\begin{array}{l}\text { Growth in } \\
\text { Local Debt }\end{array}$ & $\begin{array}{c}\text { Growth in } \\
\text { Foreign Debt }\end{array}$ & $\begin{array}{c}\text { Growth in } \\
\text { Related Party } \\
\text { Debt }\end{array}$ & $\begin{array}{c}\text { Growth in Paid } \\
\text { in Capital }\end{array}$ \\
\hline & (1) & (2) & (3) & (4) \\
\hline Constant & $\begin{array}{r}1.1335 \\
(0.4222)\end{array}$ & $\begin{array}{c}-0.6397 \\
(0.4869)\end{array}$ & $\begin{array}{r}0.6131 \\
(0.4159)\end{array}$ & $\begin{array}{r}0.3137 \\
(0.3391)\end{array}$ \\
\hline Lagged Value & $\begin{array}{r}-0.0787 \\
(0.0282)\end{array}$ & $\begin{array}{c}-0.0597 \\
(0.0175)\end{array}$ & $\begin{array}{r}-0.0663 \\
(0.0164)\end{array}$ & $\begin{array}{r}-0.0915 \\
(0.0283)\end{array}$ \\
\hline Inflation & $\begin{array}{r}0.5428 \\
(0.3385)\end{array}$ & $\begin{array}{r}0.1361 \\
(0.4265)\end{array}$ & $\begin{array}{r}0.3679 \\
(0.4013)\end{array}$ & $\begin{array}{r}0.0300 \\
(0.1034)\end{array}$ \\
\hline Depreciation $_{\mathrm{t}-1}$ & $\begin{array}{r}-0.0165 \\
(0.0687)\end{array}$ & $\begin{array}{r}-0.0427 \\
(0.0895)\end{array}$ & $\begin{array}{r}-0.0774 \\
(0.0937)\end{array}$ & $\begin{array}{r}-0.0077 \\
(0.0288)\end{array}$ \\
\hline Depreciation $_{t}$ & $\begin{array}{r}0.1798 \\
(0.0792)\end{array}$ & $\begin{array}{r}0.3517 \\
(0.1055)\end{array}$ & $\begin{array}{r}0.2480 \\
(0.1160)\end{array}$ & $\begin{array}{r}0.0276 \\
(0.0298)\end{array}$ \\
\hline Depreciation $_{\mathrm{t}+1}$ & $\begin{array}{r}-0.1092 \\
(0.0952)\end{array}$ & $\begin{array}{r}-0.0472 \\
(0.1187)\end{array}$ & $\begin{array}{r}-0.1568 \\
(0.1223)\end{array}$ & $\begin{array}{r}0.1079 \\
(0.0411)\end{array}$ \\
\hline Depreciation $_{\mathrm{t}+2}$ & $\begin{array}{r}0.0092 \\
(0.0971)\end{array}$ & $\begin{array}{r}0.0135 \\
(0.1167)\end{array}$ & $\begin{array}{r}-0.0504 \\
(0.1370)\end{array}$ & $\begin{array}{r}0.0281 \\
(0.0436)\end{array}$ \\
\hline $\begin{array}{l}\text { Industry/Year Fixed } \\
\text { Effects? } \\
\text { Firm Fixed Effects? }\end{array}$ & $\begin{array}{l}Y \\
Y\end{array}$ & $\begin{array}{l}Y \\
Y\end{array}$ & $\begin{array}{l}Y \\
Y\end{array}$ & $\begin{array}{l}\mathrm{Y} \\
\mathrm{Y}\end{array}$ \\
\hline No. of Obs. & 3,153 & 3,153 & 3,153 & 4,377 \\
\hline R-Squared & 0.5127 & 0.4912 & 0.4644 & 0.4310 \\
\hline
\end{tabular}

\footnotetext{
Note: The dependent variable is the growth in debt borrowed from local persons in column (1), the growth in debt borrowed from foreign persons in column (2), the growth in debt borrowed from related parties in column (3), and the growth in paid in capital in column (4). The sample used in all specifications is comprised of U.S. multinationals operating in emerging markets. Each specification includes industry/year and firm fixed effects. "Lagged Value" is the log of the value of the component of sales or financial capital in the previous period. "Inflation" is the change in the producer price index over the period. Changes in consumer price indices are used if changes in producer price indices are not available. The time sub-scripted "Depreciation" variables are a set of dummies equal to one in the year prior to, year of, and the two years following a depreciation. Heteroskedasticity-consistent standard errors that correct for clustering of errors by firm appear in parentheses.
} 
Appendix Table 1

Sample Information By Industry and Data Source

\begin{tabular}{|c|c|c|c|}
\hline Industry name & Total Obs & $\begin{array}{c}\% \text { in BEA } \\
\text { sample }\end{array}$ & $\begin{array}{c}\% \text { in WS } \\
\text { sample }\end{array}$ \\
\hline Agricultural production-crops & 206 & $53 \%$ & $47 \%$ \\
\hline Agricultural production--livestock and animal & 122 & $25 \%$ & $75 \%$ \\
\hline Forestry & 107 & $16 \%$ & $84 \%$ \\
\hline Fishing, hunting, and trapping & 22 & $14 \%$ & $86 \%$ \\
\hline Iron ores mining & 34 & $12 \%$ & $88 \%$ \\
\hline Copper, lead, zinc, gold, and silver ores mining & 539 & $33 \%$ & $67 \%$ \\
\hline Other metallic ores mining & 134 & $19 \%$ & $81 \%$ \\
\hline Coal mining & 78 & $32 \%$ & $68 \%$ \\
\hline Crude petroleum (no refining) and natural gas & 873 & $82 \%$ & $18 \%$ \\
\hline Nonmetallic minerals mining, except fuels & 142 & $24 \%$ & $76 \%$ \\
\hline Meat products Mfg & 139 & $35 \%$ & $65 \%$ \\
\hline Dairy products Mfg & 179 & $51 \%$ & $49 \%$ \\
\hline Preserved fruits and vegetables Mfg & 323 & $71 \%$ & $29 \%$ \\
\hline Grain mill products Mfg & 723 & $58 \%$ & $42 \%$ \\
\hline Bakery products Mfg & 71 & $56 \%$ & $44 \%$ \\
\hline Beverages Mfg & 815 & $52 \%$ & $48 \%$ \\
\hline Other food and kindred products Mfg & 1328 & $43 \%$ & $57 \%$ \\
\hline Tobacco products Mfg & 282 & $55 \%$ & $45 \%$ \\
\hline Textile mill products Mfg & 1022 & $10 \%$ & $90 \%$ \\
\hline Apparel and other textile products Mfg & 474 & $37 \%$ & $63 \%$ \\
\hline Lumber and wood products Mfg & 236 & $14 \%$ & $86 \%$ \\
\hline Furniture and fixtures Mfg & 244 & $65 \%$ & $35 \%$ \\
\hline Pulp, paper, and board mills Mfg & 330 & $22 \%$ & $78 \%$ \\
\hline Other paper and allied products Mfg & 680 & $64 \%$ & $36 \%$ \\
\hline Newspapers Mfg & 144 & $8 \%$ & $92 \%$ \\
\hline Miscellaneous publishing Mfg & 164 & $70 \%$ & $30 \%$ \\
\hline Commercial printing and services Mfg & 124 & $47 \%$ & $53 \%$ \\
\hline Industrial chemicals and synthetics Mfg & 1964 & $59 \%$ & $41 \%$ \\
\hline Drugs Mfg & 1308 & $67 \%$ & $33 \%$ \\
\hline Soap, cleaners, and toilet goods Mfg & 909 & $91 \%$ & $9 \%$ \\
\hline Agricultural chemicals Mfg & 467 & $41 \%$ & $59 \%$ \\
\hline Chemical products, nec Mfg & 829 & $76 \%$ & $24 \%$ \\
\hline Integrated petroleum refining and extraction & 189 & $9 \%$ & $91 \%$ \\
\hline Petroleum refining without extraction & 100 & $100 \%$ & $0 \%$ \\
\hline Petroleum and coal products, nec & 117 & $69 \%$ & $31 \%$ \\
\hline Rubber products Mfg & 580 & $48 \%$ & $52 \%$ \\
\hline Miscellaneous plastics products Mfg & 590 & $62 \%$ & $38 \%$ \\
\hline Leather and leather products Mfg & 130 & $18 \%$ & $82 \%$ \\
\hline Glass products Mfg & 362 & $52 \%$ & $48 \%$ \\
\hline Stone, clay, concrete, gypsum, etc. Mfg & 973 & $9 \%$ & $91 \%$ \\
\hline Ferrous Metals Mfg & 766 & $11 \%$ & $89 \%$ \\
\hline Nonferrous Metals Mfg & 531 & $22 \%$ & $78 \%$ \\
\hline Metal cans, forgings, and stampings Mfg & 378 & $56 \%$ & $44 \%$ \\
\hline Cutlery, hardware, and screw products Mfg & 172 & $90 \%$ & $10 \%$ \\
\hline Heating equipment, plumbing fixtures, etc Mfg & 201 & $45 \%$ & $55 \%$ \\
\hline Metal services, ordnance, \& fabricated metal Mfg & 213 & $68 \%$ & $32 \%$ \\
\hline Engines and turbines Mfg & 113 & $59 \%$ & $41 \%$ \\
\hline Farm and garden machinery Mfg & 62 & $50 \%$ & $50 \%$ \\
\hline Construction, mining, \& materials handling Mfg & 396 & $80 \%$ & $20 \%$ \\
\hline Metalworking machinery Mfg & 104 & $36 \%$ & $64 \%$ \\
\hline
\end{tabular}




\section{Appendix Table 1 \\ Sample Information By Industry and Data Source}

\begin{tabular}{lc|cc} 
& & \% in BEA & \% in WS \\
Industry name & Total Obs & sample & $41 \%$ \\
sample \\
\hline Special industry machinery Mfg & 179 & $59 \%$ & $45 \%$ \\
General industrial machinery Mfg & 197 & $55 \%$ & $41 \%$ \\
Computer and office equipment Mfg & 579 & $59 \%$ & $23 \%$ \\
Refrigeration and service industry machinery Mfg & 267 & $77 \%$ & $24 \%$ \\
Industrial machinery and equipment, nec Mfg & 111 & $76 \%$ & $48 \%$ \\
Household appliances Mfg & 296 & $52 \%$ & $74 \%$ \\
Household audio \& video, \& communications Mfg & 655 & $26 \%$ & $32 \%$ \\
Electronic components and accessories Mfg & 1737 & 771 & $48 \%$ \\
Electronic and other electric equipment, nec Mfg & 1451 & $68 \%$ & $32 \%$ \\
Motor vehicles and equipment Mfg & 283 & $29 \%$ & $71 \%$ \\
Other transportation equipment, nec Mfg & 232 & $49 \%$ & $51 \%$ \\
Measuring, scientific, \& optical instruments Mfg & 310 & $89 \%$ & $11 \%$ \\
Medical instruments \& supplies \& ophthalmic Mfg & 80 & $73 \%$ & $28 \%$ \\
Photographic equipment and supplies Mfg & 396 & $65 \%$ & $35 \%$ \\
Miscellaneous manufacturing industries & & &
\end{tabular}

Note: The table provides the number of firm observations in each industry covered in the sample. The share in the BEA sample indicates the share of observations that are observations of multinational affiliates while the share in the WS sample refers to the share of observations of locally owned firms taken from Worldscope. 